\title{
Prevalence of Sleep Disturbances in Pediatric Cancer Patients and Their Diagnosis and Management
}

\author{
Irtiza N. Sheikh*(D), Michael Roth and Peter L. Stavinoha*D \\ Division of Pediatrics and Patient Care, The University of Texas MD Anderson Cancer Center, \\ 1515 Holcombe Blvd., Houston, TX 77030, USA; mroth1@mdanderson.org \\ * Correspondence: isheikh1@mdanderson.org (I.N.S.); pstavinoha@mdanderson.org (P.L.S.)
}

Citation: Sheikh, I.N.; Roth, M.; Stavinoha, P.L. Prevalence of Sleep Disturbances in Pediatric Cancer Patients and Their Diagnosis and Management. Children 2021, 8, 1100 https://doi.org/10.3390/

children 8121100

Academic Editor: Karen Moody

Received: 2 November 2021

Accepted: 23 November 2021

Published: 29 November 2021

Publisher's Note: MDPI stays neutral with regard to jurisdictional claims in published maps and institutional affiliations.

Copyright: (c) 2021 by the authors. Licensee MDPI, Basel, Switzerland. This article is an open access article distributed under the terms and conditions of the Creative Commons Attribution (CC BY) license (https:// creativecommons.org/licenses/by/ $4.0 /)$.

\begin{abstract}
Sleep disturbances represent an understudied yet common source of distress among pediatric cancer patients and survivors, with deleterious effects on quality of life. Sleep issues stem from multiple risk factors, yet individual contributors are difficult to isolate, consequently impeding the identification of targets for intervention. In many pediatric cancer patients, disrupted sleep and its negative impact on quality of life continue into adulthood and may affect various functional domains. This literature review highlights the types and prevalence of sleep disturbances in pediatric cancer patients during active treatment and through survivorship. Potential etiological and risk factors for disturbed sleep are summarized, including the effects of cancer and its treatment, psychosocial and family factors, as well as individual-patient aspects, such as genetics, mood and coping skills. While existing assessment and management strategies are reviewed, the literature is incomplete, and significant gaps emerge in our understanding of sleep disturbances in pediatric cancer patients and survivors. The review concludes with recommendations of areas where further research is needed. The aims of this review include increasing clinicians' awareness of sleep disturbances as a significant source of poor quality of life in pediatric cancer patients and survivors and directing researchers to gaps in our understanding of sleep disturbances in pediatric cancer patients and survivors.
\end{abstract}

Keywords: sleep disturbance; insomnia; excessive daytime sleepiness; pediatric cancer; survivorship; adolescents and young adults

\section{Introduction}

Cancer in the pediatric and adolescent population (1-19 years old) remains one of the three leading causes of death in the United States [1]. However, advances in the treatment of pediatric cancer have led to significant increases in long-term survival, highlighting the need to address not only survival but treatment-associated morbidity and improved quality of life as well [2,3]. Among quality-of-life manifestations, children, adolescents, and young adults report sleep disturbances during and after treatment [4-7]. Indeed, sleep issues and their sequelae appear to be common in pediatric cancer patients and survivors, with almost half experiencing some form of sleep disturbance $[8,9]$. The most common etiologies of poor sleep in patients and survivors include increased daytime sleepiness and insomnia, followed by increased time to sleep onset, decreased sleep duration, and overall poor sleep quality, issues that may be manageable or treatable [8-11]. Sleep disturbances may directly result from cancer and its treatment, as well as from multiple other risk factors, many of which lead to a bidirectional relationship between sleep and physical and psychological distress [12-14]. This multifactorial relationship between pediatric cancer and sleep disturbances is illustrated in Figure 1.

The harmful effects of non-restorative sleep on the quality of life of pediatric cancer patients remain an understudied aspect of cancer care and survivorship [12]. The goal of this integrated review was to synthesize the literature on sleep disturbances in patients and survivors of childhood cancer, summarize known and suspected etiologies, highlight 
potentially fruitful intervention paradigms, and identify areas where further research is needed. The review begins with an overview of the direct effects of cancer and treatments on sleep, followed by environmental and psychological factors that may affect sleep quality. Finally, common sleep assessments and interventions are reviewed, followed by recommendations for further research to refine the clinical identification and management of sleep disturbances in this population.

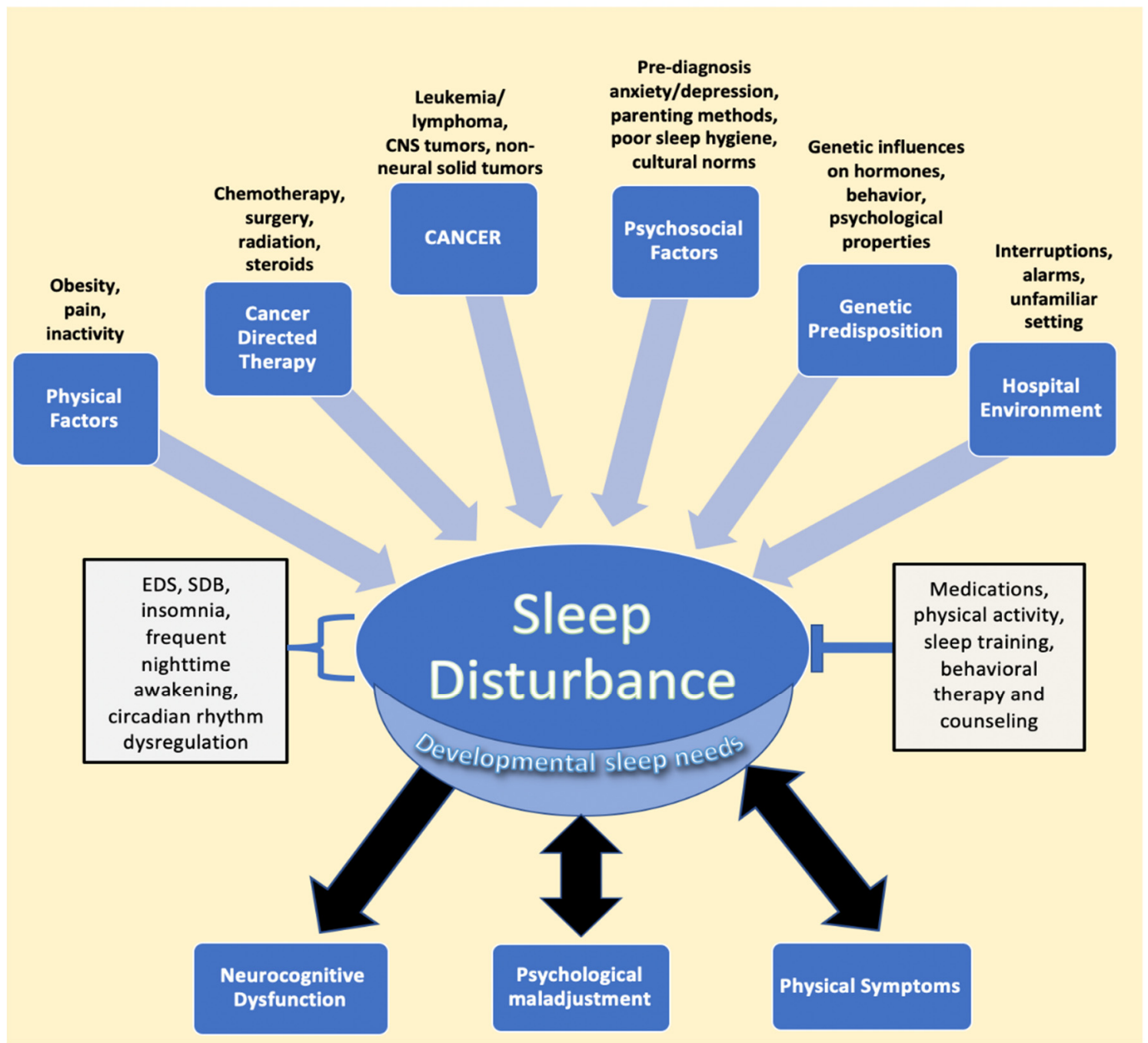

Figure 1. Factors impacting sleep in children diagnosed with cancer. The figure describes the various entities described in the literature that lead to sleep disturbance, followed by the resulting sequalae of negatively impacted sleep. EDS, SDB, frequent nighttime awakening, and circadian rhythm dysregulation are components of disturbed sleep, while interventions such as medications, physical activity, sleep training, and counseling represent mitigating factors that relieve sleep issues. Developmental sleep needs are affected globally by sleep disturbances, despite the fact that children of different ages require different amounts of sleep. Psychological maladjustment and physical symptoms, such as pain, have been found to have a bidirectional relationship with sleep issues. Abbreviations: CNS, central nervous system; EDS, excessive daytime sleepiness; $\mathrm{SDB}$, sleep disordered breathing.

\section{Methodology}

This literature review represents a scoping review in which the question identified was in regard to the current breadth of literature as it relates to the prevalence, cause, diagnosis, and treatment of sleep disturbances in cancer. We then identified the peer-reviewed literature that was relevant to the question, using PubMed, MEDLINE (Ovid), and Google Scholar databases. Examples of search terms that were used included, "sleep issues in pediatrics", "sleep disturbances in pediatric cancer", "sleep disturbances in pediatric cancer 
survivorship", "diagnosing sleep issues in pediatric patients with cancer", "treating sleep disorders in pediatrics", and "treatment of sleep issues in pediatrics". In order to describe sleep issues during treatment, as well as survivorship, this review considered studies that included children and adolescents who had been diagnosed between the ages of 0 to 18 years old. Studies that did not include patients with a history of pediatric cancer were excluded. In terms of data that described the management of sleep issues in pediatric cancer patients, we included studies that evaluated pharmacological and non-pharmacological interventions in pediatric and adolescent patients, regardless of their cancer status. Studies describing survivorship and sleep issues in survivorship included patients of all ages, including adults. Studies that described the tools and surveys used to diagnose patients with sleep disorders were included if they involved pediatric and adolescent patients, regardless of cancer status.

\section{Clinical Implications of Sleep Issues}

The importance of sleep in developing children cannot be overstated. Sleep represents a complex, multi-staged process required for survival, daily functioning, neurocognitive and physical development [15]. Moreover, per the American Academy of Sleep Medicine, developmental sleep needs change as children get older, generally requiring lesser amounts of sleep in adolescence.

Poor sleep in children is associated with deleterious effects on mood and neurocognition; a higher risk of clinical depression and anxiety; increased behavioral difficulties, including increased rates of hyperactivity; and less success in school $[13,14,16,17]$. In terms of physical health, children with sleep deficiencies or delayed sleep onset times have been found to be at higher risk of obesity and chronic health problems, such as hypertension and diabetes [18-20]. There also exists a reciprocal relationship between sleep and pain in which pain leads to disturbed sleep and poor sleep heightens the perception of pain, a relationship that is understudied in pediatric cancer patients and survivors [12,21,22].

Cancers such as leukemia are most common in those between the ages of 0-14 while central nervous system (CNS) tumors are more commonly seen in ages 15-19 [23]. Considering that certain cancers are more prevalent in different age groups than others and may affect sleep differently, the types of sleep disturbances more commonly observed in each age group may differ as well. However, excessive daytime sleepiness (EDS), a form of hypersomnolence that makes it difficult for children and adolescents to stay awake during daytime activities, is one of the most common ramifications of sleep disturbances in pediatric cancer patients, overall [15,24]. Compared to other types of sleep issues, EDS can have a similar impact on children's mood, attention and performance in school and their cognition [8,25-27]. In fact, among younger cancer survivors compared to adolescents, sleep deprivation has a stronger effect on cognition, which indicates that disrupted sleep has a more deleterious effect on the younger, developing brain $[28,29]$. Regardless of cancer type, sleep disruption is associated with difficulties in multiple domains, including mood regulation, attention, academic performance, task efficiency, processing speed, and fatigue, as well as increases in risk-taking behavior, such as tobacco use [14,15,26,27,30-38]. These impacts on quality of life pose a challenge for clinicians and are a call to action for researchers to improve outcomes for pediatric cancer patients.

\section{Relationship between Cancer and Treatment and Sleep in Pediatric Cancer}

EDS and SDB are the most common sleep issues seen in patients and survivors of hematological malignancies, as well as solid tumors, such as sarcomas, impacting as many as $60 \%$ and $40 \%$ of patients, respectively, and they are even more common in those with CNS tumors [2]. While the direct role that these cancers play in causing sleep issues is unclear, sleep disturbances occur past the treatment phase, at times more than 5 years after treatment, as demonstrated in a study by Clanton et al. of adult survivors of childhood cancer [14]. Chemotherapy, steroids, and radiation therapy are the mainstays of pediatric cancer therapy and also play a significant role in altering sleep patterns [39]. Changes in 
sleep during treatment have been observed in a wide array of malignancies, including non-neural solid tumors, hematological cancers, and CNS tumors, despite the differences in the specific chemotherapies administered $[39,40]$. Hospitalization is also a component of treatment in which initial or subsequent admissions have been shown to negatively affect sleep in pediatric cancer patients [41,42]. Although patients treated in the outpatient setting tend to have better sleep quality than those in the inpatient setting, they still have an elevated risk for poor sleep quality during active treatment. This is evidenced in a study by Zupanec et al., where greater than $80 \%$ of ALL patients between the ages of 4 to 18 years old on outpatient maintenance chemotherapy described poor sleep characterized by increased nighttime awakenings and wake time after sleep onset when compared to pediatric norms [40].

In the sections below, the effects of cancer on sleep during treatment and into survivorship are explored, followed by a discussion on the role treatment itself plays in contributing to sleep issues in patients and survivors.

\subsection{Effects of Hematological Malignancies and Non-Central Nervous System (CNS) Solid Tumor Cancers on Sleep}

Nearly $40 \%$, and, in some cases, greater than $80 \%$, of pediatric leukemia patients report some form of sleep disturbance, with insomnia being the most prevalent; however, there is a need to describe the direct impact of pediatric health conditions, such as cancer, on sleep $[2,40,43,44]$. Researchers have explored the biology of the circadian clock in leukemia cells and propose that alterations in the circadian rhythm of cells allow for unchecked replication [45-49]. There is a need for further research to determine the direct effects of hematological malignancies on sleep; the relationship between circadian gene expression in cancer cells and circadian-rhythm-dysregulation-related sleep disruption may represent a starting point for such an investigation.

In contrast to hematological malignancies, non-neural solid tumors may play a more direct and measurable role in causing sleep disturbances. They can result in OSA or SDB because of their anatomic location relative to the upper and lower airways and may necessitate surgical removal to relieve the obstruction [50]. However, outside of a case report of a spinal osteochondroma leading to sleep apnea or studies with mixed cancer diagnoses, no significant studies have isolated the role of pediatric sarcomas in sleep issues $[10,50,51]$. Nunes et al. presented one of the few studies that recognized that patients with sarcoma have greater difficulty with sleep and fatigue, possibly due to associated bone pain [52].

In pediatric leukemia survivorship, there is wide variation in the reported prevalence of sleep disturbances, with rates ranging from $13 \%$ to $50 \%$ in acute lymphoblastic leukemia survivors $[51,53]$. These differences in rates are compounded by reports of pediatric leukemia survivors who do not experience clinically poorer sleep than their sibling controls [51,54]; this contrasts with reports that indicate that leukemia survivors report disturbed sleep more than a decade after treatment [53]. Conflicting data on sleep in leukemia survivors lack a satisfactory explanation and highlight the need for further research to discover the true changes in sleep.

Similar to its hematological counterpart, the effects of lymphoma on sleep in survivorship represent another opportunity for further investigation. Research from the Childhood Cancer Survivor study looking at the factors that influence fatigue and poor sleep in adult survivors of childhood Hodgkin lymphoma (HL) demonstrated that survivors with a high body mass index (BMI) and significant bodily pain were more likely to experience EDS [55]. In that study, those with at least "medium" pain were five times more likely to experience poor sleep quality. In reviewing the effect of BMI on sleep, the effect on HL survivors is similar to those of obese survivors of CNS tumors, with higher BMI scores correlating with higher risks of sleep issues [56]. This highlights that BMI is a predictive factor that affects the sleep quality of lymphoma survivors and may be extrapolated to be a cause of disturbed sleep in other survivors, regardless of cancer type. 
There is a significant lack of research on the direct effects of non-CNS cancers on sleep in both patients on treatment and those in survivorship. The results of current studies highlight that non-CNS cancers can directly impact patients' physiological, psychosomatic, and anatomical features to disrupt sleep. Each point of disruption, such as pain, BMI, and physical-activity limitations, may serve as a modifiable target for interventions to improve sleep quality in patients and survivors [55,57-61]. Moreover, as further explained below, the type of cancer and its location may help clinicians predict the various types of sleep disturbances in these individuals.

\subsection{Effects of CNS Tumors on Sleep}

Nearly $80 \%$ of patients with CNS tumors experience sleep issues, with EDS being the most common in survivorship, as described in a study by Rosen et al., where greater than $60 \%$ of CNS tumor patients experienced EDS in survivorship [2,32]. Those with tumors of the brainstem, thalamus, or hypothalamus are the most frequent cancer patients referred for sleep studies; brain tumors are the second leading cause of secondary narcolepsy [62]. More than a quarter of survivors of pediatric brain tumors are also noted to suffer from insomnia [63]. However, research into the causes of sleep disturbances in pediatric CNS tumor patients is lacking compared to that in pediatric CNS tumor survivors. Examples indicate that the location of CNS tumors and disruption of neural structures that regulate sleep through hormonal control are the strongest examples of the direct effects of brain tumors on sleep [64-66]. Craniopharyngioma, a relatively common pediatric brain tumor that typically affects the hypothalamus, can disrupt melatonin secretion due to damage to the suprachiasmatic nucleus, leading to daytime sleepiness and poorer quality of life [67-70]. Posterior fossa tumors, including those at the brainstem, can result in apneic episodes during sleep, narcolepsy, or SDB, due to infiltration of respiratory centers, leading to EDS [2,62,71-73]. Interestingly, tumors in areas that are not ordinarily associated with sleep, such as the cerebellum, can lead to sleep disturbances, with potentially fatal consequences stemming from respiratory failure due to central sleep apnea, indicating that the cerebellum, primarily thought to direct motor function, may also have a role to play in controlling respiration, and the disruption of that respiration control leads to central sleep apnea $[65,71,74]$. Moreover, as Lee et al. describe, the effects of therapies, such as chemotherapy and radiation, on the cerebellum in contributing to sleep apnea is unclear but is probably a contributing factor to the observed central sleep apnea [74]. The effects of various pediatric CNS tumors indicate that, taking into account different locations and comparing their impact on sleep during treatment represent fruitful areas of investigation. This is especially important in pediatric oncology, considering that medulloblastomas, which occur in the cerebellum, are among the most common CNS tumors in children [75].

In adult survivors of pediatric CNS tumors, EDS continues to remain the main source of sleep disruption, followed by issues such as increased sleep onset latency, insomnia, and SDB [2,6,26,32,33,39,62,63,67,68,76-78]. Moreover, CNS tumor survivors with high BMI scores had lower levels of melatonin and were at a higher risk of hypersomnia, narcolepsy, and SDB, indicating that hormonal disruption continues into survivorship and is a significant component of sleep disturbance, especially in those with high BMIs in the range of obesity $[51,68,76,79]$.

While associations have been documented between EDS and brain tumors in the pediatric cancer population, the etiologies of certain sleep disturbances are not always clear. For example, resolution of SDB does not always lead to an improvement in EDS, suggesting that EDS is a multifactorial problem due to inefficient sleep, significant night awakenings, or circadian rhythm disorders that may manifest from varying sources $[78,80]$.

Overall, the literature examining the impact of brain tumors on sleep indicates that the location of a brain tumor, its effect on hormone disruption, and its structural disruption of the brain contribute to sleep disturbances $[67,69,71,74]$. Moreover, EDS is a significant source of distress in patients and can result due to radiation, chemotherapy, or surgery, and as Rosen et al. demonstrate, it can continue into survivorship [32]. Pediatric CNS tumor 
patients and survivors represent an important population for research into the direct effects of cancer on sleep, especially as pediatric CNS tumors are the most frequent pediatric cancer referred for sleep studies [2].

\subsection{Effects of Chemotherapy on Sleep}

Patients undergoing chemotherapy report significant sleep disturbances, characterized by increased nighttime awakenings and restlessness $[40,81,82]$. In a sample of mainly leukemia and non-Hodgkin lymphoma patients, $95 \%$ of adolescents undergoing chemotherapy experienced disrupted or low-quality sleep at least three times a week that was associated with tiredness, decreased alertness, and decreased satisfaction with the prior night's sleep quality [30].

In terms of specific risk factors and mechanisms, some patients who report sleep disturbances during chemotherapy have been found to have gene polymorphisms in genes encoding Interleukin-6 (IL-6) and tumor necrosis factor (TNF) that lead to elevated cytokine levels in the context of inadequate sleep [83]. As shown by Cheung et al. in a study looking at ALL survivors at a median of 7 years following diagnosis, the effects of chemotherapy on disturbed sleep, such as increased nighttime awakenings, may persist well into survivorship, as a result of an increase in cortisol, cytokines, and the associated physiologic cascade of immune and inflammatory responses [38,84]. These sleep issues have been shown to lead to worsened neurobehavioral outcomes, such as aggression, attention difficulties, and learning issues $[85,86]$.

Chemotherapy also plays a role in increasing the risk of developing psychological disturbances associated with impaired sleep, including anxiety, mood disorders, and behavioral issues [38,84]. Further research is needed to identify the extent to which chemotherapy independently affects sleep during treatment and survivorship, as well as to improve our understanding of the underlying risk factors and mechanisms of sleep disturbances that result from chemotherapy [81].

\subsection{Effects of Steroid Treatment on Sleep}

Steroids such as dexamethasone and prednisone are commonly used in the treatment of cancer patients and have been found to contribute to insomnia in adolescent acute lymphoblastic leukemia patients, some of whom require sleep aids [2]. Dexamethasone, in particular, is associated with poorer sleep quality compared to those on prednisone, longer time spent napping to compensate for inefficient nighttime sleep than prednisone, and disruption of REM sleep [87-90]. As evidenced by a study in ALL patients between the ages of 5 and 18 years old, dexamethasone is also associated with changes in circadian rhythm activity and an increased feeling of fatigue [91]. Sanford et al. also demonstrated, through the evaluation of patients with ALL on maintenance treatment, that gender differences may exist in experienced sleep issues, considering that inadequate sleep duration and quality due to dexamethasone appeared to be exaggerated in females [92].

More research is needed to fully understand the mechanisms of sleep disturbance that result from steroid treatment and why some agents (e.g., dexamethasone) appear to have more impact than others (e.g., prednisone). The differing effects of the two steroids may be attributable to the nearly three-fold longer half-life, stronger potency, and increased CNS penetration of dexamethasone when compared to prednisone [93,94]. Further, in a study exploring the mechanism behind dexamethasone's effects on sleep, pediatric leukemia patients on dexamethasone with certain genotypes for the genes $I L-6$, polymerase deltainteracting protein 3 (POLDIP3), or $\alpha_{2}$-Heremans-Schmid glycoprotein (AHSG), which encodes a hepatic protein, were affected most negatively in terms of sleep duration and efficiency, again indicating that patient-specific characteristics increase vulnerability to sleep difficulties under certain conditions and treatments [95].

There is a consensus that steroids lead to increased daytime napping and nighttime insomnia; as they are a mainstay of cancer treatment, practitioners should be aware of the sleep disruption that they can cause. As with chemotherapy, more research is necessary to 
ascertain the impact of individual steroid agents on sleep independent of other factors, as well as to better identify patient characteristics that may lead to greater vulnerability to sleep disturbance with steroids.

\subsection{Effects of Radiation Therapy on Sleep}

Few works in the literature exist regarding the direct effects of radiation therapy on sleep in pediatric cancer patients. Cranial radiation affects brain structures, such as the suprachiasmatic nucleus that regulates sleep and wakefulness, through direct injury to those structures $[31,56,96,97]$. Effects of such radiation-induced injuries to the sleepregulating structures in the hypothalamic-pituitary axis, including the SCN, may persist into adulthood [56,76,96-98].

Endocrine changes secondary to radiation therapy may also have a role in affecting sleep years after treatment. For example, adults who were treated as children with cranial radiation therapy (CRT) and reported difficulty with wakefulness after sleep demonstrated lower growth-hormone peak levels after an insulin challenge [96]. Considering that the hypothalamus regulates growth hormone release and sleep, both functions that are potentially affected by CRT, further research is needed to determine the interplay not only between the disruption of growth hormone release due to CRT and sleep but the long-term impact of CRT on the brain structures involved in the hormonal control of sleep $[99,100]$.

\subsection{Effects of the Hospital Environment on Sleep}

The hospital environment leads to shorter total sleep duration and difficulty remaining asleep during inpatient stays [41,81,101-103]. Hospitalized pediatric cancer patients with disrupted sleep experience greater levels of fatigue and tend to sleep longer during the day to compensate for nighttime disruptions that are at least partly related to nighttime room entries and exits, excessive lights, and noise [41,42,104]. When comparing specific cancers, Graef et al. described that hospitalized pediatric patients between the ages of 4 and 19 years old with medulloblastoma exhibited drastically shorter sleep durations and higher sleep onset latency than pediatric patients with ALL or non-CNS solid tumor patients [105]. Such studies highlight the potential for optimizing the inpatient environment and clinical practices as intervention targets to improve sleep in pediatric cancer inpatients.

\section{Psychological and Behavioral Factors That Affect Sleep}

Inherent psychological states, such as temperament, ability to cope with the cancer diagnosis, mood, and behavior, can affect sleep following a cancer diagnosis; they are also factors that are affected by sleep disturbances themselves. Considering that nearly a quarter of pediatric cancer patients and survivors report clinical depression or anxiety, it is important to explore the bidirectional relationship between mood and sleep [106]. During pediatric leukemia treatment, a child's temperament, coping skills, and self-calming skills are impacted by a cancer diagnosis and lead to an increase in psychological distress [44]. In these patients, psychological distress most commonly leads to difficulty falling asleep, awakening in the middle of the night, and irregular sleep; however, how the disrupted sleep alters the mood of such patients is unclear [44].

Although research into the bidirectional relationship between mood and disturbed sleep in pediatric cancer patients during treatment is lacking, research in those in survivorship is informative. In survivors, sleep disturbances contribute to the development of depression, post-traumatic symptoms, and anxiety, similar to other pediatric populations $[27,31,53]$. Insomnia is the most common sleep issue that has a strong bidirectional relationship with anxiety, a phenomenon that is also observed in survivors of childhood leukemia, as detailed by Zhou et al., wherein adult survivors of childhood cancer with insomnia experienced elevated anxiety levels $[13,63,107]$. Inversely, similar to mood disorders that impact sleep in non-cancer pediatric populations, large studies, such as those from the Childhood Cancer Study, have shown that depression in pediatric cancer survivors leads to an increased prevalence of sleep issues, such as increased EDS [31,108]. When 
analyzing the interplay of sleep disturbances and mood, a vicious cycle results in which sleep disturbances can represent both a contributor to, and a consequence of, psychological stress [27].

Hospitalization for cancer treatment is associated with factors such as anxiety during procedures and child and parental co-sleeping, which may continue in outpatient care and persist well after the completion of treatment $[44,109]$. Indeed, parental behaviors change as a result of a childhood cancer diagnosis [110-112]. Studies such as the one by McCarthy et al., regarding parents of pediatric ALL patients, have shown that co-sleeping is adopted by parents to alleviate both parental and child anxiety but is strongly associated with ineffective sleep [44,112]. Researchers such as McCarthy et al. and Simard et al. have described that parents' learned behaviors, such as giving patients food and drink prior to bedtime and using comforting techniques, are factors that may exacerbate inefficient sleep [112,113].

Practitioners should be aware that mood, behavior, and the inherent psychological predisposition of the patient and caregiver play significant roles in sleep. However, there is a reciprocal relationship in which sleep also alters patients' emotions and moods. Therefore, addressing these interconnected and multifactorial etiologies is important to breaking the cycle of disturbed sleep and mood.

\section{Clinical Assessment and Measurement of Sleep Disturbances in Children with Cancer}

When evaluating patients for sleep disturbances, clinicians must assess various components of sleep quality, a broad term that encompasses the amount of sleep, sleep latency, the need for sleep aids, and the extent to which sleep affects daytime functioning [114]. An assessment of sleep disturbances in children, with or without cancer, begins with a comprehensive history and physical examination [115]. Objective measures, such as BMI, evaluation of the oral cavity for tonsillar hypertrophy, and blood-pressure measurements, may help discover sequelae related to SDB and snoring [115]. Factors such as the use of television prior to sleep; family and academic pressure; and differing cultures, such as those where co-sleeping is encouraged or bedtimes are less rigid, must also be accounted for when determining contributors to inefficient sleep $[115,116]$. Measures such as polysomnography, actigraphy, sleep diaries, and sleep questionnaires serve as supplemental tools to the history and physical examination and provide a more complete picture of the source and type of sleep disturbances experienced.

Polysomnography and wrist actigraphy represent two objective measures of sleep, while sleep diaries and surveys are influenced by subjective input. While polysomnography is considered the gold standard for diagnosing SDB and sleep limb movement disorders, it may not be feasible in some settings because of the expense, the need for a childfriendly sleep laboratory, and the inability to diagnose sleep disorders associated with behavior $[115,117,118]$. Wrist actigraphy provides sleep data through a continuous monitor that measures activity such as sleep/wake cycles and sleep efficiency, but it is poorly equipped to evaluate the stages of sleep [119]. When used alongside a sleep diary, the data from both modalities are effective at assessing sleep quality [118,120]. Although it is a subjective measure, sleep diaries maintained by the parent or child provide insight into sleep quantity and timing on a consistent nightly basis [115,120].

Self-reported questionnaires are imperfect but valuable and convenient tools to categorize and quantify the presence and severity of sleep disturbances [121]. As a testament to the usefulness of sleep surveys, the American Academy of Sleep Medicine used data from parent- and child-reported sleep questionnaires to develop consensus recommendations for sleep duration in children and adolescents [7]. A variety of sleep questionnaires, such as the Children's Sleep Habits Questionnaire and Sleep Disturbance Scale for Children, are reliable surveys for assessing multiple components of sleep, including duration of sleep and disorders of initiating and maintaining sleep; they have also been used to measure sleep in studies of pediatric cancer patients [43,44,121-123]. However, the Patient-Reported 
Outcomes Measurement Information System pediatric sleep scale is the only measure that has been validated specifically in the pediatric cancer population [124].

The benefits of these surveys include their affordability and ability to evaluate a wide range of sleep disturbances through self-reported methods. However, in surveys reported by parents on behalf of patients, there was a risk of over- or under-reporting the severity of sleep issues [122,123]. Some questionnaires are also limited in the ages in which they have been studied and can be reliably used.

There are various objective and subjective tools available to clinicians to investigate sleep disturbances in the children. These tools can generally be used together to provide a more complete picture of sleep issues and their impact on daily functioning. However, there is a need to develop questionnaires and validity studies that specifically target pediatric cancer patients, while taking into account cancer-specific factors, such as treatment and cancer type. Regardless of their crude nature, sleep surveys are an efficient and valid way for clinicians to identify sleep disturbances that may lead to the faster initiation of intervention strategies to mitigate the negative functional and quality-of-life impacts of sleep problems in this population. Table 1 summarizes a variety of sleep-assessment methods for clinicians to use to evaluate pediatric cancer patients and survivors.

Table 1. Summary of selected sleep-reporting tools and their utility in assessing sleep disturbances.

\begin{tabular}{|c|c|c|c|}
\hline Sleep Reporting Tools & Form of Assessment & Population & Uses \\
\hline $\begin{array}{l}\text { Children Sleep Habits } \\
\text { Questionnaire [122] }\end{array}$ & $\begin{array}{l}\text { 35-item, parent } \\
\text { questionnaire, } \\
\text { analyzes } 8 \text { different } \\
\text { sleep domains }\end{array}$ & $\begin{array}{l}\text { Parent-reported } \\
\text { questionnaire: ages } \\
4-10 \text { years }\end{array}$ & $\begin{array}{l}\text { Broadly assesses sleep disturbances with behavioral } \\
\text { and medical causes. } \\
\text { Evaluates bedtime resistance, sleep onset delay, } \\
\text { sleep duration, sleep anxiety, nighttime awakening, } \\
\text { parasomnia, SDB, and daytime sleepiness. }\end{array}$ \\
\hline $\begin{array}{l}\text { Sleep Disturbances Scale } \\
\text { for Children [123] }\end{array}$ & $\begin{array}{l}\text { 26-item questionnaire } \\
\text { that analyzes } 5 \\
\text { different } \\
\text { sleep domains }\end{array}$ & $\begin{array}{l}\text { Parent- and } \\
\text { self-reported: ages } \\
\text { 3-16 years [125] }\end{array}$ & $\begin{array}{l}\text { Categorizes the general type of sleep } \\
\text { disturbance experienced. } \\
\text { Assesses sleep initiation and maintenance disorders, } \\
\text { arousal disorders, sleep-wake transition disorders, } \\
\text { excessive somnolence, and sleep hyperhidrosis. }\end{array}$ \\
\hline $\begin{array}{l}\text { Epworth Sleepiness } \\
\text { Scale for Children and } \\
\text { Adolescents [126] }\end{array}$ & 8-question survey & $\begin{array}{l}\text { Modified scale for } \\
\text { self-reporting: ages } \\
12-18 \text { years }\end{array}$ & $\begin{array}{l}\text { Measures the effects of daytime sleepiness on } \\
\text { adolescents' physical and mental health, including } \\
\text { effects on school performance. }\end{array}$ \\
\hline $\begin{array}{l}\text { Pediatric Daytime } \\
\text { Sleepiness Scale [127] }\end{array}$ & 8-question survey & $\begin{array}{l}\text { Self-reported survey } \\
\text { validated for } \\
\text { children and } \\
\text { adolescents in } \\
\text { middle school: ages } \\
\text { 11-15 years }\end{array}$ & $\begin{array}{l}\text { Determines severity of daytime sleepiness and } \\
\text { effects on outcomes in school performance. } \\
\text { Correlates daytime sleepiness with changes in mood. }\end{array}$ \\
\hline $\begin{array}{c}\text { Patient-Reported } \\
\text { Outcomes Measurement } \\
\text { Information System } \\
\text { Pediatric Sleep } \\
\text { Disturbance and } \\
\text { Sleep-Related } \\
\text { Impairment item } \\
\text { banks [124,128] }\end{array}$ & $\begin{array}{l}2 \text { portions: } 15 \text {-item } \\
\text { questionnaire } \\
\text { assessing sleep } \\
\text { disturbances, 13-item } \\
\text { questionnaire } \\
\text { assessing sleep- } \\
\text { related impairment }\end{array}$ & $\begin{array}{l}\text { Self-reported version: } \\
\text { ages } 8-17 \text { years; } \\
\text { parent-reported } \\
\text { version: ages } \\
\text { 5-17 years }\end{array}$ & $\begin{array}{c}\text { Assesses difficulties in falling and staying asleep } \\
\text { and daytime sleepiness and their effects on } \\
\text { daytime functioning. }\end{array}$ \\
\hline $\begin{array}{l}\text { Children's Report of } \\
\text { Sleep Patterns [129] }\end{array}$ & $\begin{array}{l}\text { 60-item questionnaire } \\
\text { with } 3 \text { domains: Sleep } \\
\text { Patterns, Sleep } \\
\text { Hygiene Index and } \\
\text { Sleep } \\
\text { Disturbance scale }\end{array}$ & $\begin{array}{l}\text { Self-reported } \\
\text { questionnaire: ages } \\
8-12 \text { years }\end{array}$ & $\begin{array}{c}\text { Use } 3 \text { domains, collectively or independently, to } \\
\text { determine the source of sleep issues (sleep habits } \\
\text { prior to bedtime, sleep patterns, and } \\
\text { sleep disturbances). }\end{array}$ \\
\hline
\end{tabular}


Table 1. Cont.

\begin{tabular}{|c|c|c|c|}
\hline Sleep Reporting Tools & Form of Assessment & Population & Uses \\
\hline $\begin{array}{l}\text { Pittsburgh Sleep Quality } \\
\text { Index [130] }\end{array}$ & $\begin{array}{l}19 \text { sleep items } \\
\text { analyzing sleep } \\
\text { quality, assessed in } \\
\text { healthy and } \\
\text { non-healthy adults }\end{array}$ & $\begin{array}{c}\text { Self-reported } \\
\text { questionnaire } \\
\text { initially designed for } \\
\text { adults, with no } \\
\text { pediatric-specific } \\
\text { form } \\
\text { Has been used in the } \\
\text { pediatric cancer } \\
\text { population }[8,43]\end{array}$ & $\begin{array}{l}\text { Measures general sleep quality, taking into account } \\
\text { sleep duration, sleep latency, daytime issues due to } \\
\text { ineffective sleep, and use of sleep medication. }\end{array}$ \\
\hline Sleep Diary [118] & $\begin{array}{l}\text { Subjective tool to } \\
\text { record nightly } \\
\text { sleep information }\end{array}$ & $\begin{array}{l}\text { Self- or } \\
\text { parent-reported: all } \\
\text { pediatric age groups }\end{array}$ & $\begin{array}{l}\text { Follows a wide array of comprehensive data for each } \\
\text { night's sleep: duration of sleep, sleep onset latency, } \\
\text { nighttime awakenings, and bedtime behavior. } \\
\text { Preferred over questionnaires for further details on } \\
\text { sleep-wake cycles. } \\
\text { Most accurate when combined with actigraphy. }\end{array}$ \\
\hline Actigraphy [131] & $\begin{array}{l}\text { Wristwatch-like device } \\
\text { used in the } \\
\text { outpatient setting }\end{array}$ & $\begin{array}{l}\text { All pediatric } \\
\text { age groups }\end{array}$ & $\begin{array}{l}\text { Assesses sleep-wake information, such as sleep } \\
\text { onset, total sleep time, and nighttime awakening. } \\
\text { Most accurate when combined with a sleep diary. }\end{array}$ \\
\hline Polysomnography [132] & $\begin{array}{l}\text { Diagnostic tool for the } \\
\text { evaluation of } \\
\text { sleep-disordered } \\
\text { breathing, } \\
\text { especially OSA }\end{array}$ & $\begin{array}{l}\text { All pediatric patients; } \\
\text { more data are } \\
\text { needed for patients } \\
<6 \text { months [133] }\end{array}$ & $\begin{array}{l}\text { Gold standard for diagnosing sleep-disordered } \\
\text { breathing and establishing non-invasive positive } \\
\text { pressure ventilation. settings for therapy of OSA } \\
\text { Can also be used to diagnose limb } \\
\text { movement disorders. }\end{array}$ \\
\hline
\end{tabular}

\section{Managing and Preventing Sleep Disturbances}

There are no official guidelines on preventative or treatment methods for sleep disturbances in pediatric cancer patients and survivors; in addition, no approaches have been evaluated in large randomized controlled trials, and no systematic research has examined specific interventions associated with individual or combined risk factors [134]. Given the mosaic of potential etiologies for sleep disturbance in these patients, additional research is necessary to disentangle the independent contributions of factors, including cancerspecific risks, treatment-related factors, environmental and behavioral contributors, and psychological components. Regardless of modality, the importance of early intervention is underscored by the fact that sleep disturbances can continue into adulthood for childhood cancer survivors [11,106,135].

The Predisposing, Precipitating, and Perpetuating Model of Insomnia is a potentially useful model for identifying intervention targets for the sleep disturbances observed in pediatric cancer patients and survivors [27]. This model considers factors that predispose patients to insomnia or sleep disturbances, such as genetics and family history. The sleep disturbances are then precipitated by factors such as the stress of treatment, hospitalization, and the psychosocial and physiological changes that are associated with diagnosis and treatment $[27,41]$. Twin studies and isolation of mutations in genes, such as the transporter region of the serotonin gene (5HTTLPR), have demonstrated that genetic factors also predispose patients to an increased risk of emotional disturbance due to sleep issues, perpetuating the bidirectional relationship between sleep and emotional issues [13,136,137]. When patients return home from an inpatient stay, psychological and physical stress, such as constant anxiety, perpetuate maladaptive sleep habits that developed throughout inpatient treatment, including making it harder to fall asleep at home or experiencing nighttime awakenings [109]. The model represents points in the cycle that serve as preventative and intervention targets and indicates that effective treatment requires managing a multitude of factors, including the cancer itself, the side effects of treatment, and the psychosocial states of the patient and his/her family. 
Although no large randomized controlled trials have evaluated the management of sleep issues in the pediatric cancer population, small pilot studies have evaluated various modalities in the inpatient setting as potential interventions to manage and improve sleep, such as massage and physical activity $[138,139]$. Complementary and alternative methods (CAMs), such as massage, yoga, hypnosis, and acupuncture, have been used in adult and pediatric cancer patients, yet their effectiveness and safety in pediatric cancer patients have not been widely evaluated $[134,140,141]$. Such methods, especially non-pharmacological approaches, represent another avenue that may have a role in managing and preventing sleep issues in pediatric cancer patients, but there is a lack of current research on this issue [134].

Educating families on sleep hygiene (e.g., appropriate wake and sleep times and activities prior to sleep) has also been used to mitigate sleep issues during cancer treatment. On the basis of the understanding that sleep habits change during cancer treatment and parenting behaviors play a role in influencing patients' sleep, investigators educated families of pediatric ALL outpatients on sleep issues and provided them with relaxation techniques to influence family behavior and promote good sleep hygiene. This program resulted in longer nighttime sleep duration and shorter wake time after nighttime awakening, indicating that education and relaxation techniques are viable management strategies in other pediatric cancer and survivor populations [106,142]. Moreover, while there are no established methods for preventing sleep issues in pediatric cancer patients, educating parents in the general population on normal sleep patterns in children is an effective method of avoiding more entrenched issues, such as insomnia, or identifying them earlier; such educational programs should be trialed more broadly in families of pediatric cancer patients [143].

Sleep and exercise may be reciprocally beneficial treatment paradigms for sleep disturbance, where an improvement in one can result in an improvement in the other [144-146]. This is supported by a study of adolescents with various types of cancers including hematological malignancies and solid tumors who participated in a program where physical activity during treatment was compared to those with lower levels of activity. The researchers demonstrated that those with greater frequency and duration of physical activity during treatment and survivorship experienced significantly improved sleep quality and in turn, directly improved quality of life [147]. Considering that BMI has been shown to serve as a risk factor for EDS in children, modifying dietary choices along with activity is also vital to mitigating the effects of sleep disturbances $[51,78]$. In a study of cancer patients between the ages of 8 to 18 years old who were actively undergoing chemotherapy, higher levels of daytime physical activity were shown to decrease waking after sleep onset and increase sleep efficacy [144]. Overall, increasing physical activity and decreasing BMI in the pediatric cancer population serve as direct methods to improve sleep quality and reduce the effects of poor sleep on functional outcomes.

Various psychological therapies may hold promise for managing sleep disturbances in pediatric cancer patients. Adventure-based training is a combination of self-reflection techniques and sustained physical activity; in a small randomized controlled trial, it was shown to counter cancer-related fatigue [148]. Similar studies can be implemented to discover the role of adventure-based training in improving sleep in cancer survivors. Another psychological therapy that may have utility in the pediatric cancer population is cognitive behavioral therapy for insomnia, an effective method used in adult cancer survivors to improve sleep onset and decrease nighttime awakenings [135,149]. A similar, online version of cognitive behavioral therapy for insomnia is currently underway to determine its utility in pediatric survivors with insomnia [150].

Although the use of sleep medication in the non-cancer pediatric population is common, its use and safety in the pediatric cancer population is less studied [151]. Per the American Academy of Sleep Medicine, US Food and Drug Administration-approved medications that are known to be effective pharmacological treatments in adults with insomnia have not been studied in children [152-154]. For example, melatonin is an over-the-counter 
supplement that has shown some efficacy in treating sleep onset and circadian rhythm problems, including in obese survivors of childhood craniopharyngioma $[69,115,155]$. There is an obvious need to determine the efficacy and safety of sleep medications in cancer patients and survivors in the short- and long-term, including possible drug-chemotherapy interactions [156,157]. As Merz et al., detail, sleep medications in the pediatric cancer population may inadvertently perpetuate sleep disturbances by not treating the root cause, such as altered circadian rhythms, poor sleep hygiene, maladaptive sleep habits and behaviors, and a non-conducive sleep environment [106]. Moreover, the researchers explain that pediatric patients who habitually use sleep aids during treatment and survivorship may be at risk of suppressing their natural sleep cycle and falsely assume that medication is necessary to sleep.

Considering that EDS and SDB are significant contributors to sleep issues in the pediatric cancer population, there is a need to adopt treatment modalities for these sleep disturbances. Methods such as weight loss, positive pressure therapy, and adenotonsillectomy have been shown to provide relief from OSA, a form of SDB, in the general population [158-161]; because of their wide acceptance, these methods should be explored in the pediatric cancer population. Overall, there is an apparent need to focus on the safety and efficacy of pharmacological and non-pharmacological interventions in treating sleep disturbances in the pediatric cancer population [134]. Outside of physical activity, the current literature is inconclusive on medication and supportive care techniques for pediatric cancer patients, leaving a significant portion of this population vulnerable to the downstream effects of disturbed sleep. The various management strategies used to address sleep disturbances in pediatric cancer patients are described in Figure 2.

\section{Established Methods}

- Physical activity programs (inpatient/ outpatient)

- Education on sleep and sleep hygiene in children with cancer

- Non-invasive positive pressure ventilation (e.g., CPAP/BiPAP)

- Melatonin

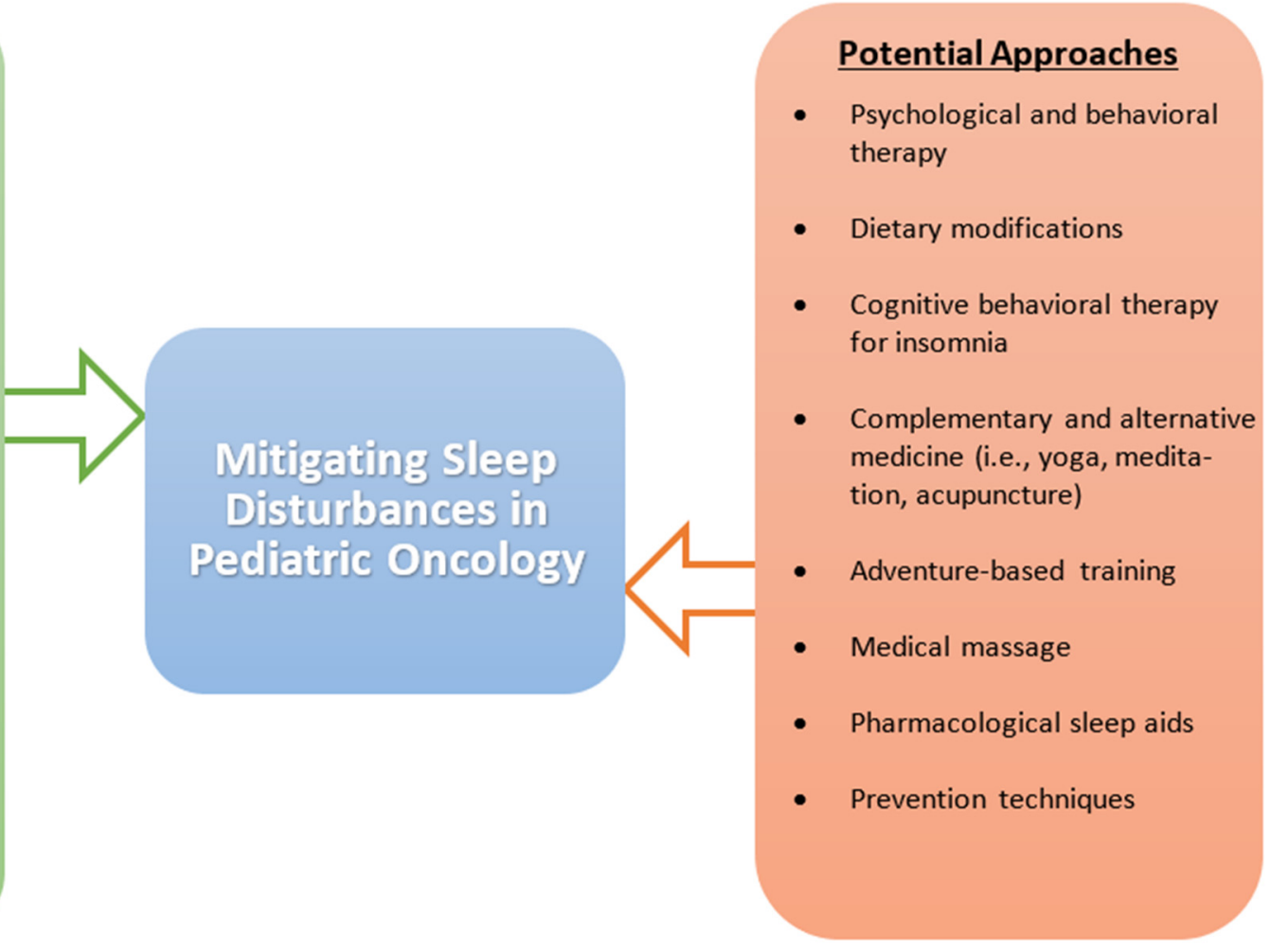

Figure 2. Established and potential management strategies to address sleep disturbances in pediatric cancer patients. The figure compares established methods that have been found to positively impact sleep to potential methods that require more investigation, specifically in the pediatric cancer population. Abbreviations: BiPAP, bi-level positive airway pressure; CPAP, continuous positive airway pressure. 


\section{Future Directions and Limitations}

Although nearly half of pediatric cancer patients and survivors experience disturbed sleep, there are significant gaps in our understanding of the role cancer plays in sleep issues and how to diagnose, prevent, and manage sleep problems. As described throughout this review, there are gaps in the literature in describing sleep issues due to the direct effects of cancers, such as the relationship between leukemia and circadian gene expression and the impact on sleep, as well as the direct role that solid tumors play in leading to disturbed sleep $[45,46,49,52]$. When describing a lack of the literature in patient characteristics that are affected by sleep issues during active treatment, there is a need to further describe the effect of inefficient sleep on mood and the bidirectional relationship of anxiety and sleep $[63,106,107]$. Moreover, while there are genetic factors that have been elucidated in terms of the genes that predispose a pediatric patient to further sleep issues and associated mood disorders, more work is needed to clarify genes already implicated and to discover other genetic variations as well [137]. When determining the best standard of practices to diagnose sleep disturbances, further studies are needed to guide clinicians in using validated instruments, such as the PROMIS surveys, and to standardize the use of modalities that assess sleep quality in pediatric cancer patients and survivors, including polysomnography, actigraphy, and various sleep questionnaires. These tools can then be utilized throughout treatment and survivorship to follow patients' progression. In terms of treating sleep issues, data on both pharmacological and non-pharmacological modalities are severely lacking in pediatric cancer treatment and survivorship populations. Preliminary studies of sleep hygiene education targeted at children and parents, physical activity, and supportive care methods, such as massage, may serve as a springboard to broader and well-designed clinical trials to better understand the application of various interventions, given the multiple potential etiologies for sleep disturbances in this population $[106,138,139,142]$. Consequently, randomized controlled trials in the pediatric cancer population could help us determine the efficacy and safety of sleep medications, such as melatonin and sedating agents; the timing and intensity of sleep education; modalities of psychological interventions; and lifestyle interventions to ameliorate sleep difficulties. Sleep interventions that have been studied in the general pediatric population may serve as models for studying effective therapies to improve sleep in pediatric cancer patients and survivors. Further research is also needed to determine how to prevent maladaptive sleep changes. Determining how genetics, obesity, pain tolerance, treatment paradigms, cancer type, patient and family psychosocial characteristics, and sleep-related parenting behavior predispose patients to poor sleep may help us make progress toward that goal. A better understanding of etiological factors may lead to highly personalized intervention paradigms. When evaluating the gaps in the literature in regard to the long-term effects of the cancer diagnosis and its associated treatment on sleep, further research is needed to determine the longer-lasting effects of the malignancy and treatment on areas such as persistent inflammatory response and damage to structures of the brain. Moreover, similar to pediatric cancer survivors, larger prospective studies would assist in determining the psychological of a cancer diagnosis on sleep and the effects of sleep issues on the mood and cognitive outcomes of survivors. These gaps are further detailed in Figure 3.

Considering that our literature review represented a scoping review, we identified limitations that place the results of our study in context. The discovery of the literature that we commented on was not based on a systemic methodology, and, thus, we did not evaluate the quality of the publications cited, despite ensuring that the papers included were published in peer-reviewed journals. Since the literature was researched manually through a database, e.g., PubMed, we may have missed certain studies on sleep disturbances in pediatric cancer patients, and our review is prone to selection bias. Moreover, due to the nature of the scoping review, the search for the literature required multiple different searches in the databases, thus increasing the variability of the literature cited. 


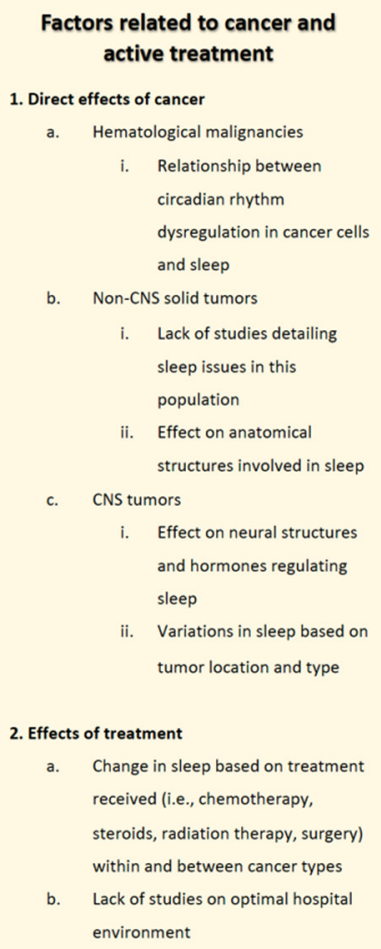

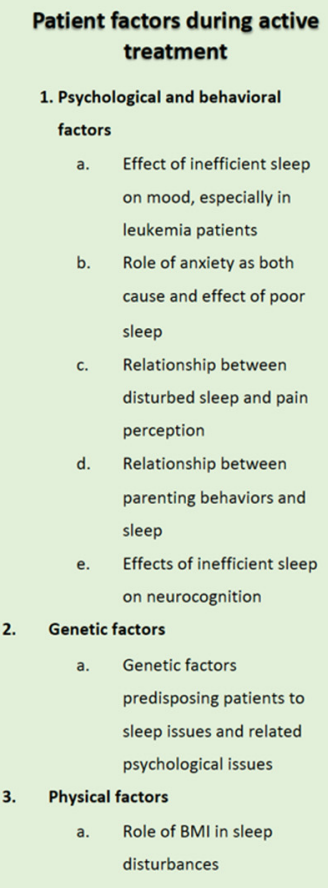

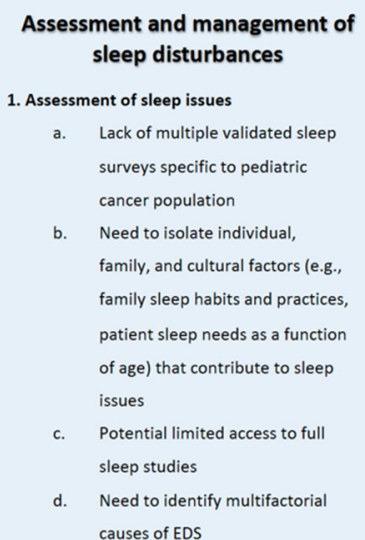

2. Management of sleep issues

a. Need for RCTs for pharmacological and nonpharmacological interventions

b. Lack of approved medications fo sleep in pediatric cancer population

c. Lack of evidence-based preventative measures and educational curricula

\section{Survivorship and functional outcome}

1. Residual effects of cancer types

a. Differences in sleep between leukemia survivors and general population

b. Variations in sleep based on solid (CNS/Non-CNS) tumor location

2. Effects of treatment

a. Inflammatory changes due to chemotherapy

b. Role of chemotherapy in increasing psychological disturbances and impact on sleep

c. Persistent radiation therapy-induced changes to sleep hormone releasing neural structures

3. Psychological and behavioral factors

a. Long-term bidirectional relationship between mood disorders ( i.e. depression and anxiety) and disturbed sleep

b. Long term effects of sleep on neurocognition in survivors, including performance in school, $1 Q$, daytime functioning

c. Impact on long term outcomes, quality of life

Figure 3. Gaps in knowledge on sleep disturbances in children with cancer. The figure describes areas where there is a need for further investigation in regard to sleep issues, their assessment and management, and their causes and sequalae during and after treatment, including many years into survivorship. Abbreviations: BMI, body mass index; CNS, central nervous system; EDS, excessive daytime sleepiness; IQ, intelligence quotient; RCT, randomized controlled trial.

\section{Conclusions}

In pediatric cancer patients, sleep disturbances are common and multifactorial and have significant effects on the quality of life during treatment and survivorship. Regardless of cancer type, sleep changes, such as daytime sleepiness, insomnia, increased sleep onset time, and poor sleep quality, are common in pediatric cancer patients and survivors. The disease, treatment, home environment, and psychological predisposition of the patient play a role in the development and maintenance of sleep disturbances. While all children with cancer are at risk for sleep disturbances and the resulting deleterious effects on daily functioning, survivors of CNS tumors are affected the most significantly.

Ultimately, improved sleep may be an essential component to enhancing short- and long-term functional, health, and quality-of-life outcomes of pediatric cancer patients and adult survivors. Improved sleep may be essential to reaching these goals. Increased research into sleep changes in pediatric cancer patients and survivors may help us develop diagnostic and treatment guidelines for general and oncology practitioners.

Author Contributions: All authors contributed to the drafting and revision of this manuscript. All authors have approved the submitted version of this manuscript and agree to be personally accountable for their own contribution and ensuring the accuracy and integrity of the work presented and documented in the literature. All authors have read and agreed to the published version of the manuscript.

Funding: This research received no external funding.

Conflicts of Interest: The authors declare no conflict of interest. 


\section{References}

1. Cunningham, M.R.; Walton, M.A.; Carter, P.M. The Major Causes of Death in Children and Adolescents in the United States. New Engl. J. Med. 2018, 379, 2468-2475. [CrossRef]

2. Rosen, G.; Brand, S.R. Sleep in children with cancer: Case review of 70 children evaluated in a comprehensive pediatric sleep center. Support. Care Cancer 2011, 19, 985-994. [CrossRef]

3. O'Leary, M.; Krailo, M.; Anderson, J.R.; Reaman, G.H. Progress in Childhood Cancer: 50 Years of Research Collaboration, a Report from the Children's Oncology Group. Semin. Oncol. 2008, 35, 484-493. [CrossRef] [PubMed]

4. Hart, N.C.; Palermo, T.M.; Rosen, C.L. Health-related quality of life among children presenting to a pediatric sleep disorders clinic. Behav. Sleep. Med. 2005, 3, 4-17. [CrossRef] [PubMed]

5. Walker, A.J.; Johnson, K.P.; Miaskowski, C.; Lee, K.A.; Gedaly-Duff, V. Sleep quality and sleep hygiene behaviors of adolescents during chemotherapy. J. Clin. Sleep Med. 2010, 6, 439-444. [CrossRef] [PubMed]

6. Mandrell, B.N.; Wise, M.; Schoumacher, R.A.; Pritchard, M.; West, N.; Ness, K.K.; Crabtree, V.M.; Merchant, T.E.; Morris, B. Excessive daytime sleepiness and sleep-disordered breathing disturbances in survivors of childhood central nervous system tumors. Pediatr. Blood Cancer 2012, 58, 746-751. [CrossRef] [PubMed]

7. Paruthi, S.; Brooks, L.J.; D'Ambrosio, C.; Hall, W.A.; Kotagal, S.; Lloyd, R.M.; Malow, B.A.; Maski, K.; Nichols, C.; Quan, S.F.; et al. Consensus Statement of the American Academy of Sleep Medicine on the Recommended Amount of Sleep for Healthy Children: Methodology and Discussion. J. Clin. Sleep Med. 2016, 12, 1549-1561. [CrossRef] [PubMed]

8. Daniel, C.L.; Aggarwal, R.; Schwartz, L.A. Sleep in Adolescents and Young Adults in the Year After Cancer Treatment. J. Adolesc. Young Adult Oncol. 2017, 6, 560-567. [CrossRef]

9. Chen-Lim, L.M.; Davis, K.F. Children With Cancer: Should You be Concerned About Their Sleep? J. Pediatr. Nurs. Nurs. Care Child. Fam. 2010, 25, e15. [CrossRef]

10. Wright, M. Children receiving treatment for cancer and their caregivers: A mixed methods study of their sleep characteristics. Pediatr. Blood Cancer 2011, 56, 638-645. [CrossRef] [PubMed]

11. Fortmann, J.; Fisher, A.; Hough, R.; Gregory, A.; Pugh, G. Sleep Quality Among Teenagers and Young Adults with Cancer. Cancer Nurs. 2021, 44, 13-19. [CrossRef] [PubMed]

12. Allen, J.M.; Graef, D.M.; Ehrentraut, J.H.; Tynes, B.L.; Crabtree, V.M. Sleep and Pain in Pediatric Illness: A Conceptual Review. CNS Neurosci. Ther. 2016, 22, 880-893. [CrossRef] [PubMed]

13. Alvaro, P.K.; Roberts, R.; Harris, J.K. A Systematic Review Assessing Bidirectionality between Sleep Disturbances, Anxiety, and Depression. Sleep 2013, 36, 1059-1068. [CrossRef]

14. Clanton, N.R.; Klosky, J.L.; Li, C.; Jain, N.; Srivastava, D.K.; Mulrooney, D.; Zeltzer, L.; Stovall, M.; Robison, L.L.; Krull, K.R. Fatigue, vitality, sleep, and neurocognitive functioning in adult survivors of childhood cancer: A report from the Childhood Cancer Survivor Study. Cancer 2011, 117, 2559-2568. [CrossRef] [PubMed]

15. Mindell, J.A.; Owens, J.A. A Clinical Guide to Pediatric Sleep: Diagnosis and Management of Sleep Problems, 3rd ed.; Wolters Kluwer Health/Lippincott Williams \& Wilkins: Philadelphia, PA, USA, 2010.

16. Owens, J. Insufficient sleep in adolescents and young adults: An update on causes and consequences. Pediatrics 2014, 134, e921-e932. [CrossRef] [PubMed]

17. Dahl, R.E. Sleep and the developing brain. Sleep 2007, 30, 1079-1080. [CrossRef]

18. Snell, E.K.; Adam, E.K.; Duncan, G.J. Sleep and the Body Mass Index and Overweight Status of Children and Adolescents. Child Dev. 2007, 78, 309-323. [CrossRef] [PubMed]

19. Rudnicka, A.R.; Nightingale, C.M.; Donin, A.S.; Sattar, N.; Cook, D.G.; Whincup, P.H.; Owen, C.G. Sleep Duration and Risk of Type 2 Diabetes. Pediatrics 2017, 140, e20170338. [CrossRef]

20. Navarro-Solera, M.; Carrasco-Luna, J.; Pin-Arboledas, G.; González-Carrascosa, R.; Soriano, J.M.; Codoñer-Franch, P. Short Sleep Duration Is Related to Emerging Cardiovascular Risk Factors in Obese Children. J. Pediatr. Gastroenterol. Nutr. 2015, 61, 571-576. [CrossRef]

21. Valrie, C.R.; Bromberg, M.H.; Palermo, T.; Schanberg, L.E. A systematic review of sleep in pediatric pain populations. J. Dev. Behav. Pediatr. 2013, 34, 120-128. [CrossRef]

22. Lewin, D.S.; Dahl, R.E. Importance of sleep in the management of pediatric pain. J. Dev. Behav. Pediatr. 1999, 20, 244-252. [CrossRef]

23. Siegel, R.L.; Miller, K.D.; Fuchs, H.E.; Jemal, A. Cancer Statistics, 2021. CA A Cancer J. Clin. 2021, 71, 7-33. [CrossRef] [PubMed]

24. Chokroverty, S. Overview of sleep \& sleep disorders. Indian J. Med. Res. 2010, 131, 126-140.

25. Blunden, S.; Lushington, K.; Lorenzen, B.; Martin, J.; Kennedy, D. Neuropsychological and psychosocial function in children with a history of snoring or behavioral sleep problems. J. Pediatr. 2005, 146, 780-786. [CrossRef] [PubMed]

26. Kathy, R.; Anna, G.; Gallicchio, L.; Gamaldo, C. Sleep disordered breathing risk in childhood cancer survivors: An exploratory study. Pediatr. Blood Cancer 2015, 62, 693-697. [PubMed]

27. Daniel, L.; Kazak, A.E.; Li, Y.; Hobbie, W.; Ginsberg, J.; Butler, E.; Schwartz, L. Relationship between sleep problems and psychological outcomes in adolescent and young adult cancer survivors and controls. Support. Care Cancer 2016, 24, 539-546. [CrossRef]

28. O'Brien, L.M. The neurocognitive effects of sleep disruption in children and adolescents. Child Adolesc. Psychiatr Clin. N. Am. 2009, 18, 813-823. [CrossRef] 
29. O’Brien, L.M.; Mervis, C.B.; Holbrook, C.R.; Bruner, J.L.; Smith, N.H.; McNally, N.; McClimment, M.C.; Gozal, D. Neurobehavioral correlates of sleep-disordered breathing in children. J. Sleep Res. 2004, 13, 165-172. [CrossRef]

30. Erickson, J.M.; Beck, S.L.; Christian, B.R.; Dudley, W.; Hollen, P.J.; Albritton, K.A.; Sennett, M.; Dillon, R.L.; Godder, K. Fatigue, sleep-wake disturbances, and quality of life in adolescents receiving chemotherapy. J. Pediatr. Hematol. Oncol. 2011, 33, e17-e25. [CrossRef]

31. Zeltzer, L.K.; Recklitis, C.; Buchbinder, D.; Zebrack, B.; Casillas, J.; Tsao, J.C.; Lu, Q.; Krull, K. Psychological status in childhood cancer survivors: A report from the Childhood Cancer Survivor Study. J. Clin. Oncol. 2009, 27, 2396-2404. [CrossRef]

32. Rosen, G.M.; Bendel, A.E.; Neglia, J.P.; Moertel, C.L.; Mahowald, M. Sleep in children with neoplasms of the central nervous system: Case review of 14 children. Pediatrics 2003, 112, e46-e54. [CrossRef]

33. Fisher, R.S.; Rausch, J.R.; Ferrante, A.C.; Prussien, K.V.; Olshefski, R.S.; Vannatta, K.A.; Compas, B.E.; Gerhardt, C.A. Trajectories of health behaviors across early childhood cancer survivorship. Psychooncology 2019, 28, 68-75. [CrossRef] [PubMed]

34. Beebe, D.W. Cognitive, behavioral, and functional consequences of inadequate sleep in children and adolescents. Pediatr. Clin. N. Am. 2011, 58, 649-665. [CrossRef]

35. Bourke, R.; Anderson, V.; Yang, J.S.; Jackman, A.R.; Killedar, A.; Nixon, G.M.; Davey, M.J.; Walker, A.M.; Trinder, J.; Horne, R.S. Cognitive and academic functions are impaired in children with all severities of sleep-disordered breathing. Sleep Med. 2011, 12, 489-496. [CrossRef] [PubMed]

36. Hunter, S.J.; Gozal, D.; Smith, D.L.; Philby, M.F.; Kaylegian, J.; Kheirandish-Gozal, L. Effect of Sleep-disordered Breathing Severity on Cognitive Performance Measures in a Large Community Cohort of Young School-aged Children. Am. J. Respir. Crit. Care Med. 2016, 194, 739-747. [CrossRef] [PubMed]

37. Galland, B.; Spruyt, K.; Dawes, P.; McDowall, P.S.; Elder, D.; Schaughency, E. Sleep Disordered Breathing and Academic Performance: A Meta-analysis. Pediatrics 2015, 136, e934-e946. [CrossRef] [PubMed]

38. Cheung, Y.T.; Brinkman, T.M.; Mulrooney, D.A.; Mzayek, Y.; Liu, W.; Banerjee, P.; Panoskaltsis-Mortari, A.; Srivastava, D.; Pui, C.H.; Robison, L.L.; et al. Impact of sleep, fatigue, and systemic inflammation on neurocognitive and behavioral outcomes in long-term survivors of childhood acute lymphoblastic leukemia. Cancer 2017, 123, 3410-3419. [CrossRef]

39. Kaleyias, J.; Manley, P.; Kothare, S.V. Sleep Disorders in Children with Cancer. Semin. Pediatr. Neurol. 2012, 19, 25-34. [CrossRef]

40. Zupanec, S.; Jones, H.; Stremler, R. Sleep Habits and Fatigue of Children Receiving Maintenance Chemotherapy for All and Their Parents. J. Pediatr. Oncol. Nurs. 2010, 27, 217-228. [CrossRef]

41. Lee, S.; Narendran, G.; Tomfohr-Madsen, L.; Schulte, F. A systematic review of sleep in hospitalized pediatric cancer patients. Psycho-Oncology 2017, 26, 1059-1069. [CrossRef]

42. Hinds, P.S.; Hockenberry, M.; Rai, S.N.; Zhang, L.; Razzouk, B.I.; McCarthy, K.; Cremer, L.; Rodriguez-Galindo, C. Nocturnal awakenings, sleep environment interruptions, and fatigue in hospitalized children with cancer. Oncol. Nurs. Forum. 2007, 34, 393-402. [CrossRef]

43. Steur, L.M.H.; Kolk, R.H.E.; Mooij, F.; de Vries, R.; Grootenhuis, M.A.; Kaspers, G.J.L.; Van Litsenburg, R.R.L. The prevalence and risk factors of sleep problems in pediatric oncology: Its effect on quality of life during and after cancer treatment. Expert Rev. Qual. Life Cancer Care 2016, 1, 153-171. [CrossRef]

44. Daniel, L.C.; Schwartz, L.A.; Mindell, J.A.; Tucker, C.A.; Barakat, L.P. Initial Validation of the Sleep Disturbances in Pediatric Cancer Model. J. Pediatric Psychol. 2016, 41, 588-599. [CrossRef]

45. Rahman, S.; Al-Hallaj, A.S.; Nedhi, A.; Gmati, G.; Ahmed, K.; Jama, H.A.; Trivilegio, T.; Mashour, A.; Askar, A.A. Differential Expression of Circadian Genes in Leukemia and a Possible Role for Sirt1 in Restoring the Circadian Clock in Chronic Myeloid Leukemia. J. Circadian Rhythm. 2017, 15, 3. [CrossRef] [PubMed]

46. Padmanabhan, K.; Billaud, M. Desynchronization of Circadian Clocks in Cancer: A Metabolic and Epigenetic Connection. Front. Endocrinol. 2017, 8, 136. [CrossRef] [PubMed]

47. Fu, L.; Kettner, N.M. The circadian clock in cancer development and therapy. Prog. Mol. Biol. Transl. Sci. 2013, 119, 221-282. [PubMed]

48. Savvidis, C.; Koutsilieris, M. Circadian rhythm disruption in cancer biology. Mol. Med. 2012, 18, 1249-1260. [CrossRef]

49. Haus, E.L.; Smolensky, M.H. Shift work and cancer risk: Potential mechanistic roles of circadian disruption, light at night, and sleep deprivation. Sleep Med. Rev. 2013, 17, 273-284. [CrossRef]

50. Wang, V.; Chou, D. Anterior C1-2 osteochondroma presenting with dysphagia and sleep apnea. J. Clin. Neurosci. 2009, 16, 581-582. [CrossRef]

51. Mulrooney, D.A.; Ness, K.K.; Neglia, J.P.; Whitton, J.A.; Green, D.M.; Zeltzer, L.K.; Robison, L.L.; Mertens, A.C. Fatigue and sleep disturbance in adult survivors of childhood cancer: A report from the childhood cancer survivor study (CCSS). Sleep 2008, 31, 271-281. [CrossRef]

52. Nunes, M.D.R.; Jacob, E.; Adlard, K.; Secola, R.; Nascimento, L. Fatigue and Sleep Experiences at Home in Children and Adolescents With Cancer. Oncol. Nurs. Forum. 2015, 42, 498-506. [CrossRef] [PubMed]

53. Meeske, K.A.; Siegel, S.E.; Globe, D.R.; Mack, W.J. Prevalence and Correlates of Fatigue in Long-Term Survivors of Childhood Leukemia. J. Clin. Oncol. 2005, 23, 5501-5510. [CrossRef] [PubMed]

54. Russell, K.B.; Merz, E.L.; Reynolds, K.; Schulte, F.; Tomfohr-Madsen, L. Sleep Disturbances in Survivors of Pediatric Acute Lymphoblastic Leukemia and Their Siblings. J. Pediatr. Psychol. 2020, 45, 707-716. [CrossRef] [PubMed] 
55. Rach, A.M.; Crabtree, V.M.; Brinkman, T.M.; Zeltzer, L.; Marchak, J.G.; Srivastava, D.; Tynes, B.; Lai, J.S.; Robison, L.L. Predictors of fatigue and poor sleep in adult survivors of childhood Hodgkin's lymphoma: A report from the Childhood Cancer Survivor Study. J. Cancer Surviv. 2017, 11, 256-263. [CrossRef]

56. Nolan, V.G.; Gapstur, R.; Gross, C.R.; DeSain, L.A.; Neglia, J.P.; Gajjar, A.; Klosky, J.L.; Merchant, T.E.; Stovall, M.; Ness, K.K. Sleep disturbances in adult survivors of childhood brain tumors. Qual. Life Res. 2013, 22, 781-789. [CrossRef] [PubMed]

57. Tutelman, P.R.; Chambers, C.T.; Stinson, J.N.; Parker, J.A.; Fernandez, C.V.; Witteman, H.O.; Nathan, P.C.; Barwick, M.; Campbell, F.; Jibb, L.A.; et al. Pain in Children with Cancer: Prevalence, Characteristics, and Parent Management. Clin. J. Pain 2018, 34, 198-206. [CrossRef] [PubMed]

58. Oeffinger, K.C.; Mertens, A.C.; Sklar, C.A.; Yasui, Y.; Fears, T.; Stovall, M.; Vik, T.A.; Inskip, P.D.; Robison, L.L. Obesity in Adult Survivors of Childhood Acute Lymphoblastic Leukemia: A Report from the Childhood Cancer Survivor Study. J. Clin. Oncol. 2003, 21, 1359-1365. [CrossRef]

59. Nathan, P.C.; Nachman, A.; Sutradhar, R.; Kurdyak, P.; Pole, J.D.; Lau, C.; Gupta, S. Adverse mental health outcomes in a population-based cohort of survivors of childhood cancer. Cancer 2018, 124, 2045-2057. [CrossRef]

60. Lu, Q.; Krull, K.R.; Leisenring, W.; Owen, J.E.; Kawashima, T.; Tsao, J.C.I.; Zebrack, B.; Mertens, A.; Armstrong, G.T.; Stovall, M.; et al. Pain in long-term adult survivors of childhood cancers and their siblings: A report from the Childhood Cancer Survivor Study. Pain 2011, 152, 2616-2624. [CrossRef]

61. Zhang, F.F.; Parsons, S.K. Parsons, Obesity in Childhood Cancer Survivors: Call for Early Weight Management. Adv. Nutr. 2015, 6, 611-619. [CrossRef]

62. Rosen, G.M.; Shor, A.C.; Geller, T.J. Sleep in children with cancer. Curr. Opin. Pediatr. 2008, 20, 676-681. [CrossRef]

63. Zhou, E.S.; Recklitis, C.J. Insomnia in adult survivors of childhood cancer: A report from project REACH. Support. Care Cancer 2014, 22, 3061-3069. [CrossRef] [PubMed]

64. DelRosso, L.M.; Martin, K.; Ferri, R. A not so incidental finding in a 12-year old with sleepiness and headaches. Sleep Med. 2018, 43, 31-33. [CrossRef]

65. Fujimoto, K.; Kasai, H.; Kunii, R.; Terada, J.; Tatsumi, K. Obstructive Sleep Apnea in a Severely Obese Child with Combined Central Sleep Apnea and Sleep-Related Hypoventilation Disorder Caused by a Medullary Tumor. J. Clin. Sleep Med. 2018, 14, 1071-1074. [CrossRef]

66. Ferri, L.; Filardi, M.; Moresco, M.; Pizza, F.; Vandi, S.; Antelmi, E.; Toni, F.; Zucchelli, M.; Pierangeli, G.; Plazzi, G. Non-24-Hour Sleep-Wake Rhythm Disorder and Melatonin Secretion Impairment in a Patient With Pineal Cyst. J. Clin. Sleep Med. 2017, 13, 1355-1357. [CrossRef]

67. Jacola, L.M.; Conklin, H.M.; Scoggins, M.A.; Ashford, J.M.; Merchant, T.E.; Mandrell, B.N.; Ogg, R.J.; Curtis, E.; Wise, M.S.; Indelicato, D.J.; et al. Investigating the Role of Hypothalamic Tumor Involvement in Sleep and Cognitive Outcomes Among Children Treated for Craniopharyngioma. J. Pediatr. Psychol. 2016, 41, 610-622. [CrossRef] [PubMed]

68. Gapstur, R.; Gross, C.R.; Ness, K. Factors associated with sleep-wake disturbances in child and adult survivors of pediatric brain tumors: A review. Oncol. Nurs. Forum. 2009, 36, 723-731. [CrossRef]

69. Müller, H.L.; Handwerker, G.; Wollny, B.; Faldum, A.; Sörensen, N. Melatonin secretion and increased daytime sleepiness in childhood craniopharyngioma patients. J. Clin. Endocrinol. Metab. 2002, 87, 3993-3996. [CrossRef] [PubMed]

70. Pickering, L.; Jennum, P.; Gammeltoft, S.; Poulsgaard, L.; Feldt-Rasmussen, U.; Klose, M. Sleep-wake and melatonin pattern in craniopharyngioma patients. Eur. J. Endocrinol. 2014, 170, 873-884. [CrossRef] [PubMed]

71. Ito, K.; Murofushi, T.; Mizuno, M.; Semba, T. Pediatric brain stem gliomas with the predominant symptom of sleep apnea. Int. J. Pediatr. Otorhinolaryngol. 1996, 37, 53-64. [CrossRef]

72. Marcus, C.L.; Trescher, W.H.; Halbower, A.C.; Lutz, J. Secondary narcolepsy in children with brain tumors. Sleep 2002, 25, 435-439.

73. Weil, A.G.; Muir, K.; Hukin, J.; Desautels, A.; Martel, V.; Perreault, S. Narcolepsy and Hypothalamic Region Tumors: Presentation and Evolution. Pediatr. Neurol. 2018, 84, 27-31. [CrossRef] [PubMed]

74. Lee, A.; Chen, M.L.; Abeshaus, S.; Poliakov, A.; Ojemann, J.G. Posterior fossa tumors and their impact on sleep and ventilatory control: A clinical perspective. Respir. Physiol. Neurobiol. 2013, 189, 261-271. [CrossRef]

75. Packer, R.J. Childhood brain tumors: Accomplishments and ongoing challenges. J. Child. Neurol. 2008, 23, 1122-1127. [CrossRef] [PubMed]

76. Manley, P.E.; McKendrick, K.; McGillicudy, M.; Chi, S.N.; Kieran, M.W.; Cohen, L.E.; Kothare, S.; Michael Scott, R.; Goumnerova, L.C.; Sun, P.; et al. Sleep dysfunction in long term survivors of craniopharyngioma. J. Neurooncol. 2012, 108, 543-549. [CrossRef] [PubMed]

77. Verberne, L.M.; Maurice-Stam, H.; Grootenhuis, M.A.; Van Santen, H.M.; Schouten-Van Meeteren, A.Y.N. Sleep disorders in children after treatment for a CNS tumour. J. Sleep Res. 2012, 21, 461-469. [CrossRef]

78. Brimeyer, C.; Adams, L.; Zhu, L.; Srivastava, D.K.; Wise, M.; Hudson, M.M.; Crabtree, V.M. Sleep complaints in survivors of pediatric brain tumors. Support Care Cancer 2016, 24, 23-31. [CrossRef]

79. O'Gorman, C.S.; Simoneau-Roy, J.; Pencharz, P.; MacFarlane, J.; MacLusky, I.; Narang, I.; Adeli, K.; Daneman, D.; Hamilton, J. Sleep-Disordered Breathing Is Increased in Obese Adolescents with Craniopharyngioma Compared with Obese Controls. J. Clin. Endocrinol. Metab. 2010, 95, 2211-2218. [CrossRef] 
80. Lipton, J.; Megerian, J.T.; Kothare, S.V.; Cho, Y.J.; Shanahan, T.; Chart, H.; Ferber, R.; Adler-Golden, L.; Cohen, L.E.; Czeisler, C.A.; et al. Melatonin deficiency and disrupted circadian rhythms in pediatric survivors of craniopharyngioma. Neurology 2009, 73, 323-325. [CrossRef]

81. Hockenberry, M.J.; Hooke, M.C.; Gregurich, M.A.; McCarthy, K.; Sambuco, G.; Krull, K. Symptom clusters in children and adolescents receiving cisplatin, doxorubicin, or ifosfamide. Oncol. Nurs. Forum. 2010, 37, E16-E27. [CrossRef]

82. Ameringer, S.; Elswick, R.K., Jr.; Shockey, D.P.; Dillon, R. A pilot exploration of symptom trajectories in adolescents with cancer during chemotherapy. Cancer Nurs. 2013, 36, 60-71. [CrossRef] [PubMed]

83. Vallance, K.; Yang, J.; Li, J.; Crabtree, V.M.; Hinds, P.S.; Mandrell, B.N. Disturbed sleep in pediatric patients with leukemia: The potential role of interleukin-6(-174GC) and tumor necrosis factor (-308GA) polymorphism. Oncol. Nurs. Forum. 2011, 38, E365-E372. [CrossRef]

84. Cheung, Y.T.; Lim, S.R.; Ho, H.K.; Chan, A. Cytokines as mediators of chemotherapy-associated cognitive changes: Current evidence, limitations and directions for future research. PLoS ONE 2013, 8, e81234. [CrossRef]

85. Astill, R.G.; Van der Heijden, K.B.; Van Ijzendoorn, M.H.; Van Someren, E.J. Sleep, cognition, and behavioral problems in school-age children: A century of research meta-analyzed. Psychol. Bull. 2012, 138, 1109-1138. [CrossRef]

86. Millman, R.P. Excessive sleepiness in adolescents and young adults: Causes, consequences, and treatment strategies. Pediatrics 2005, 115, 1774-1786. [CrossRef]

87. Moser, N.J.; Phillips, B.A.; Guthrie, G.; Barnett, G. Effects of dexamethasone on sleep. Pharmacol. Toxicol. 1996, 79, 100-102. [CrossRef] [PubMed]

88. Born, J.; DeKloet, E.R.; Wenz, H.; Kern, W.; Fehm, H.L. Gluco-and antimineralocorticoid effects on human sleep: A role of central corticosteroid receptors. Am. J. Physiol. 1991, 260, E183-E188. [CrossRef]

89. Rosen, G.; Harris, A.K.; Liu, M.; Dreyfus, J.; Krueger, J.; Messinger, Y.H. The effects of dexamethasone on sleep in young children with acute lymphoblastic leukemia. Sleep Med. 2015, 16, 503-509. [CrossRef] [PubMed]

90. Daniel, L.C.; Li, Y.; Kloss, J.D.; Reilly, A.F.; Barakat, L.P. The impact of dexamethasone and prednisone on sleep in children with acute lymphoblastic leukemia. Support. Care Cancer 2016, 24, 3897-3906. [CrossRef] [PubMed]

91. Rogers, V.E.; Zhu, S.; Ancoli-Israel, S.; Hinds, P.S. Impairment in circadian activity rhythms occurs during dexamethasone therapy in children with leukemia. Pediatr. Blood Cancer 2014, 61, 1986-1991. [CrossRef]

92. Sanford, S.D.; Okuma, J.O.; Pan, J.; Srivastava, D.K.; West, N.; Farr, L.; Hinds, P.S. Gender differences in sleep, fatigue, and daytime activity in a pediatric oncology sample receiving dexamethasone. J. Pediatr. Psychol. 2008, 33, 298-306. [CrossRef] [PubMed]

93. Zoorob, R.; Cender, D. A different look at corticosteroids. Am. Fam. Physician 1998, 58, 443-450.

94. Balis, F.M.; Lester, C.M.; Chrousos, G.P.; Heideman, R.L.; Poplack, D.G. Differences in cerebrospinal fluid penetration of corticosteroids: Possible relationship to the prevention of meningeal leukemia. J. Clin. Oncol. 1987, 5, 202-207. [CrossRef] [PubMed]

95. Vallance, K.; Liu, W.; Mandrell, B.N.; Panetta, J.C.; Gattuso, J.S.; Hockenberry, M.; Zupanec, S.; Yang, L.; Yang, J.; Hinds, P.S. Mechanisms of dexamethasone-induced disturbed sleep and fatigue in paediatric patients receiving treatment for ALL. Eur. J. Cancer 2010, 46, 1848-1855. [CrossRef] [PubMed]

96. Van Someren, E.J.; Swart-Heikens, J.; Endert, E.; Bisschop, P.H.; Swaab, D.F.; Bakker, P.J.; Romijn, J.A.; Fliers, E. Long-term effects of cranial irradiation for childhood malignancy on sleep in adulthood. Eur. J. Endocrinol. 2004, 150, 503-510. [CrossRef] [PubMed]

97. Khan, R.B.; Merchant, T.E.; Sadighi, Z.S.; Bello, M.S.; Lu, Z.; Sykes, A.; Wise, M.S.; Crabtree, V.M.; Zabrowski, J.; Simmons, A.; et al. Prevalence, risk factors, and response to treatment for hypersomnia of central origin in survivors of childhood brain tumors. J. Neurooncol. 2018, 136, 379-384. [CrossRef]

98. Follin, C.; Erfurth, E.M. Long-Term Effect of Cranial Radiotherapy on Pituitary-Hypothalamus Area in Childhood Acute Lymphoblastic Leukemia Survivors. Curr. Treat Options Oncol. 2016, 17, 50. [CrossRef]

99. Merchant, T.E.; Rose, S.R.; Bosley, C.; Wu, S.; Xiong, X.; Lustig, R.H. Growth hormone secretion after conformal radiation therapy in pediatric patients with localized brain tumors. J. Clin. Oncol. 2011, 29, 4776-4780. [CrossRef] [PubMed]

100. Steiger, A.; Holsboer, F. Neuropeptides and human sleep. Sleep 1997, 20, 1038-1052. [PubMed]

101. Cowherd, E.L.; Sutton, A.G.; Vincent, J.O.; Humphries, M.S.; Ritter, V.; Fine, J.; Steiner, M.J. Timing and Duration of Sleep in Hospitalized Children: An Observational Study. Hosp. Pediatr. 2019, 9, 333-339. [CrossRef]

102. Meltzer, L.J.; Davis, K.F.; Mindell, J.A. Patient and parent sleep in a children's hospital. Pediatr. Nurs. 2012, 38, 64-71.

103. Linder, L.A.; Christian, B.J. Nighttime sleep disruptions, the hospital care environment, and symptoms in elementary school-age children with cancer. Oncol. Nurs. Forum. 2012, 39, 553-561. [CrossRef]

104. Setoyama, A.; Ikeda, M.; Kamibeppu, K. Objective assessment of sleep status and its correlates in hospitalized children with cancer: Exploratory study. Pediatr. Int. 2016, 58, 842-849. [CrossRef] [PubMed]

105. Graef, D.M.; Crabtree, V.M.; Srivastava, D.K.; Li, C.; Pritchard, M.; Hinds, P.S.; Mandrell, B. Sleep and mood during hospitalization for high-dose chemotherapy and hematopoietic rescue in pediatric medulloblastoma. Psychooncology 2018, 27, 1847-1853. [CrossRef]

106. Merz, E.L.; Tomfohr-Madsen, L. Sleep Disruption in Pediatric Cancer Survivors: Conceptual Framework and Opportunities for Clinical Assessment and Behavioral Treatment. Am. J. Lifestyle Med. 2018, 12, 311-323. [CrossRef] [PubMed] 
107. Taylor, D.J.; Lichstein, K.L.; Durrence, H.H.; Reidel, B.W.; Bush, A.J. Epidemiology of Insomnia, Depression, and Anxiety. Sleep 2005, 28, 1457-1464. [CrossRef] [PubMed]

108. Chorney, D.B.; Detweiler, M.F.; Morris, T.L.; Kuhn, B.R. The Interplay of Sleep Disturbance, Anxiety, and Depression in Children. J. Pediatr. Psychol. 2007, 33, 339-348. [CrossRef]

109. Kim, H.; Zhou, E.S.; Chevalier, L.; Lun, P.; Davidson, R.D.; Pariseau, E.M.; Long, K.A. Parental Behaviors, Emotions at Bedtime, and Sleep Disturbances in Children with Cancer. J. Pediatr. Psychol. 2020, 45, 550-560. [CrossRef]

110. Williams, L.K.; McCarthy, M.C. Parent perceptions of managing child behavioural side-effects of cancer treatment: A qualitative study. Child Care Health Dev. 2015, 41, 611-619. [CrossRef]

111. Vance, Y.; Eiser, C. Caring for a child with cancer-A systematic review. Pediatr. Blood Cancer 2004, 42, 249-253. [CrossRef] [PubMed]

112. McCarthy, M.C.; Bastiani, J.; Williams, L.K. Are parenting behaviors associated with child sleep problems during treatment for acute lymphoblastic leukemia? Cancer Med. 2016, 5, 1473-1480. [CrossRef] [PubMed]

113. Simard, V.; Nielsen, T.A.; Tremblay, R.E.; Boivin, M.; Montplaisir, J.Y. Longitudinal study of preschool sleep disturbance: The predictive role of maladaptive parental behaviors, early sleep problems, and child/mother psychological factors. Arch. Pediatr. Adolesc. Med. 2008, 162, 360-367. [CrossRef]

114. Erwin, A.M.; Bashore, L. Subjective Sleep Measures in Children: Self-Report. Front Pediatr. 2017, 5, 22. [CrossRef]

115. Moturi, S.; Avis, K. Assessment and treatment of common pediatric sleep disorders. Psychiatry 2010, 7, $24-37$.

116. Owens, J.A. Introduction: Culture and Sleep in Children. Pediatrics 2005, 115, 201-203. [CrossRef] [PubMed]

117. Aurora, R.N.; Lamm, C.I.; Zak, R.S.; Kristo, D.A.; Bista, S.R.; Rowley, J.A.; Casey, K.R. Practice parameters for the non-respiratory indications for polysomnography and multiple sleep latency testing for children. Sleep 2012, 35, 1467-1473. [CrossRef]

118. Mazza, S.; Bastuji, H.; Rey, A. Objective and Subjective Assessments of Sleep in Children: Comparison of Actigraphy, Sleep Diary Completed by Children and Parents' Estimation. Front. Psychiatry 2020, 11, 495. [CrossRef]

119. Ancoli-Israel, S.; Cole, R.; Alessi, C.; Chambers, M.; Moorcroft, W.; Pollak, C.P. The role of actigraphy in the study of sleep and circadian rhythms. Sleep 2003, 26, 342-392. [CrossRef]

120. Werner, H.; Molinari, L.; Guyer, C.; Jenni, O.G. Agreement Rates Between Actigraphy, Diary, and Questionnaire for Children's Sleep Patterns. Arch. Pediatr. Adolesc. Med. 2008, 162, 350-358. [CrossRef]

121. Spruyt, K.; Gozal, D. Pediatric sleep questionnaires as diagnostic or epidemiological tools: A review of currently available instruments. Sleep Med. Rev. 2011, 15, 19-32. [CrossRef] [PubMed]

122. Owens, J.A.; Spirito, A.; McGuinn, M. The Children's Sleep Habits Questionnaire (CSHQ): Psychometric properties of a survey instrument for school-aged children. Sleep 2000, 23, 1043-1051. [CrossRef]

123. Bruni, O.; Ottaviano, S.; Guidetti, V.; Romoli, M.; Innocenzi, M.; Cortesi, F.; Giannotti, F. The Sleep Disturbance Scale for Children (SDSC). Construction and validation of an instrument to evaluate sleep disturbances in childhood and adolescence. J. Sleep Res. 1996, 5, 251-261. [CrossRef]

124. Daniel, L.C.; Gross, J.Y.; Meltzer, L.J.; Flannery, J.L.; Forrest, C.B.; Barakat, L.P. Clinical validity of the PROMIS pediatric sleep short forms in children receiving treatment for cancer. Pediatr. Blood Cancer 2020, 67, e28535. [CrossRef] [PubMed]

125. Romeo, D.M.; Bruni, O.; Brogna, C.; Ferri, R.; Galluccio, C.; De Clemente, V.; Di Jorio, M.; Quintiliani, M.; Ricci, D.; Mercuri, E. Application of the sleep disturbance scale for children (SDSC) in preschool age. Eur. J. Paediatr. Neurol. 2013, 17, $374-382$. [CrossRef]

126. Janssen, K.C.; Phillipson, S.; O'Connor, J.; Johns, M.W. Validation of the Epworth Sleepiness Scale for Children and Adolescents using Rasch analysis. Sleep Med. 2017, 33, 30-35. [CrossRef]

127. Drake, C.; Nickel, C.; Burduvali, E.; Roth, T.; Jefferson, C.; Pietro, B. The pediatric daytime sleepiness scale (PDSS): Sleep habits and school outcomes in middle-school children. Sleep 2003, 26, 455-458. [PubMed]

128. Forrest, C.B.; Meltzer, L.J.; Marcus, C.L.; de la Motte, A.; Kratchman, A.; Buysse, D.J.; Pilkonis, P.A.; Becker, B.D.; Bevans, K.B. Development and validation of the PROMIS Pediatric Sleep Disturbance and Sleep-Related Impairment item banks. Sleep 2018, 41, 1-13. [CrossRef]

129. Meltzer, L.J.; Avis, K.T.; Biggs, S.; Reynolds, A.C.; Crabtree, V.M.; Bevans, K.B. The Children's Report of Sleep Patterns (CRSP): A self-report measure of sleep for school-aged children. J. Clin. Sleep Med. 2013, 9, 235-245. [CrossRef] [PubMed]

130. Buysse, D.J.; Reynolds, C.F., 3rd; Monk, T.H.; Berman, S.R.; Kupfer, D.J. The Pittsburgh Sleep Quality Index: A new instrument for psychiatric practice and research. Psychiatry Res. 1989, 28, 193-213. [CrossRef]

131. Meltzer, L.J.; Montgomery-Downs, H.E.; Insana, S.P.; Walsh, C.M. Use of actigraphy for assessment in pediatric sleep research. Sleep Med. Rev. 2012, 16, 463-475. [CrossRef]

132. Beck, S.E.; Marcus, C.L. Pediatric Polysomnography. Sleep Med. Clin. 2009, 4, 393-406. [CrossRef]

133. DeHaan, K.L.; Seton, C.; Fitzgerald, D.A.; Waters, K.A.; MacLean, J.E. Polysomnography for the diagnosis of sleep disordered breathing in children under 2 years of age. Pediatr. Pulmonolog. 2015, 50, 1346-1353. [CrossRef]

134. Stavinoha, P.L.; Olsthoorn, I.M.; Swartz, M.C.; Nowakowski, S.; Wells, S.J.; Hicklen, R.S.; Sheikh, I.; Jang, H.J. Nonpharmacological sleep interventions for pediatric cancer patients and survivors: A systematic review protocol. Syst. Rev. 2021, 10, 166. [CrossRef] [PubMed]

135. Zhou, E.S.; Vrooman, L.M.; Manley, P.E.; Crabtree, V.M.; Recklitis, C.J. Adapted Delivery of Cognitive-Behavioral Treatment for Insomnia in Adolescent and Young Adult Cancer Survivors: A Pilot Study. Behav. Sleep Med. 2017, 15, 288-301. [CrossRef] 
136. Gregory, A.M.; Sadeh, A. Sleep, emotional and behavioral difficulties in children and adolescents. Sleep Med. Rev. 2012, 16, 129-136. [CrossRef]

137. Barclay, N.L.; Gregory, A.M. Quantitative genetic research on sleep: A review of normal sleep, sleep disturbances and associated emotional, behavioural, and health-related difficulties. Sleep Med. Rev. 2013, 17, 29-40. [CrossRef]

138. Jacobs, S.; Mowbray, C.; Cates, L.M.; Baylor, A.; Gable, C.; Skora, E.; Estrada, M.; Cheng, Y.; Wang, J.; Lewin, D.; et al. Pilot Study of Massage to Improve Sleep and Fatigue in Hospitalized Adolescents with Cancer. Pediatr. Blood Cancer 2016, 63, 880-886. [CrossRef]

139. Hinds, P.S.; Hockenberry, M.; Rai, S.N.; Zhang, L.; Razzouk, B.I.; Cremer, L.; McCarthy, K.; Rodriguez-Galindo, C. Clinical field testing of an enhanced-activity intervention in hospitalized children with cancer. J. Pain Symptom Manag. 2007, 33, 686-697. [CrossRef] [PubMed]

140. Sencer, S.F.; Kelly, K.M. Complementary and Alternative Therapies in Pediatric Oncology. Pediatr. Clin. N. Am. 2007, 54, 1043-1060. [CrossRef] [PubMed]

141. Kelly, K.M. Complementary and alternative medical therapies for children with cancer. Eur. J. Cancer 2004, 40, 2041-2046. [CrossRef] [PubMed]

142. Zupanec, S.; Jones, H.; McRae, L.; Papaconstantinou, E.; Weston, J.; Stremler, R. A Sleep Hygiene and Relaxation Intervention for Children with Acute Lymphoblastic Leukemia: A Pilot Randomized Controlled Trial. Cancer Nurs. 2017, 40, 488-496. [CrossRef] [PubMed]

143. Carter, K.A.; Hathaway, N.E.; Lettieri, C.F. Common sleep disorders in children. Am. Fam. Physician 2014, 89, 368-377.

144. Orsey, A.D.; Wakefield, D.B.; Cloutier, M.M. Physical activity (PA) and sleep among children and adolescents with cancer. Pediatr. Blood Cancer 2013, 60, 1908-1913. [CrossRef]

145. Orsey, A.D.; Wakefield, D.B. Does socioeconomic status impact physical activity and sleep among children with cancer? Pediatr. Blood Cancer 2016, 63, 2004-2010. [CrossRef]

146. Dimeo, F.C.; Stieglitz, R.-D.; Novelli-Fischer, U.; Fetscher, S.; Keul, J. Effects of physical activity on the fatigue and psychologic status of cancer patients during chemotherapy. Cancer 1999, 85, 2273-2277. [CrossRef]

147. Wu, W.W.; Jou, S.T.; Liang, S.Y.; Tsai, S.Y. The Mediating Role of Exercise on Relationships Between Fatigue, Sleep Quality, and Quality of Life for Adolescents with Cancer. Cancer Nurs. 2019, 42, E10-E19. [CrossRef]

148. Li, W.H.C.; Ho, K.Y.; Lam, K.K.W.; Lam, H.S.; Chui, S.Y.; Chan, G.C.F.; Cheung, A.T.; Ho, L.L.K.; Chung, O.K. Adventure-based training to promote physical activity and reduce fatigue among childhood cancer survivors: A randomized controlled trial. Int. J. Nurs. Stud. 2018, 83, 65-74. [CrossRef]

149. Armstrong, T.S.; Shade, M.Y.; Breton, G.; Gilbert, M.R.; Mahajan, A.; Scheurer, M.E.; Vera, E.; Berger, A.M. Sleep-wake disturbance in patients with brain tumors. Neuro-Oncology 2016, 19, 323-335. [CrossRef]

150. Peersmann, S.H.M.; van Straten, A.; Kaspers, G.J.L.; Thano, A.; van den Bergh, E.; Grootenhuis, M.A.; van Litsenburg, R.R.L. Does the guided online cognitive behavioral therapy for insomnia "i-Sleep youth" improve sleep of adolescents and young adults with insomnia after childhood cancer? (MICADO-study): Study protocol of a randomized controlled trial. Trials 2021, 22, 307. [CrossRef] [PubMed]

151. Owens, J.A.; Rosen, C.L.; Mindell, J.A. Medication use in the treatment of pediatric insomnia: Results of a survey of communitybased pediatricians. Pediatrics 2003, 111, 628-635. [CrossRef]

152. Schutte-Rodin, S.; Broch, L.; Buysse, D.; Dorsey, C.; Sateia, M. Clinical guideline for the evaluation and management of chronic insomnia in adults. J. Clin. Sleep Med. 2008, 4, 487-504. [CrossRef]

153. Lie, J.D.; Tu, K.N.; Shen, D.D.; Wong, B.M. Pharmacological Treatment of Insomnia. A Peer Rev. J. Manag. Care Hosp. Formul. Manag. 2015, 40, 759-768, 771 .

154. Minkel, J.; Krystal, A.D. Krystal, Optimizing the Pharmacologic Treatment of Insomnia: Current Status and Future Horizons. Sleep Med. Clin. 2013, 8, 333-350. [CrossRef]

155. Smits, M.G.; Nagtegaal, E.E.; van der Heijden, J.; Coenen, A.M.; Kerkhof, G.A. Melatonin for chronic sleep onset insomnia in children: A randomized placebo-controlled trial. J. Child Neurol. 2001, 16, 86-92. [CrossRef] [PubMed]

156. Mindell, J.A.; Emslie, G.; Blumer, J.; Genel, M.; Glaze, D.; Ivanenko, A.; Johnson, K.; Rosen, C.; Steinberg, F.; Roth, T.; et al. Pharmacologic management of insomnia in children and adolescents: Consensus statement. Pediatrics 2006, 117, e1223-e1232. [CrossRef] [PubMed]

157. Owens, J.A.; Moturi, S. Pharmacologic treatment of pediatric insomnia. Child Adolesc. Psychiatr. Clin. N. Am. 2009, 18, 1001-1016. [CrossRef]

158. Girbal, I.C.; Gonçalves, C.; Nunes, T.; Ferreira, R.; Pereira, L.; Saianda, A.; Bandeira, T. Non-invasive ventilation in complex obstructive sleep apnea-a 15-year experience of a pediatric tertiary center. Rev. Port. Pneumol. 2014, 20, 146-151. [CrossRef] [PubMed]

159. Marcus, C.L.; Brooks, L.J.; Draper, K.A.; Gozal, D.; Halbower, A.C.; Jones, J.; Schechter, M.S.; Ward, S.D.; Sheldon, S.H.; Shiffman, R.N.; et al. Diagnosis and management of childhood obstructive sleep apnea syndrome. Pediatrics 2012, 130, e714-e755. [CrossRef]

160. Dehlink, E.; Tan, H.-L. Update on paediatric obstructive sleep apnoea. J. Thorac. Dis. 2016, 8, $224-235$.

161. Chan, J.; Edman, J.C.; Koltai, P.J. Obstructive sleep apnea in children. Am. Fam. Physician 2004, 69, 1147-1154. 